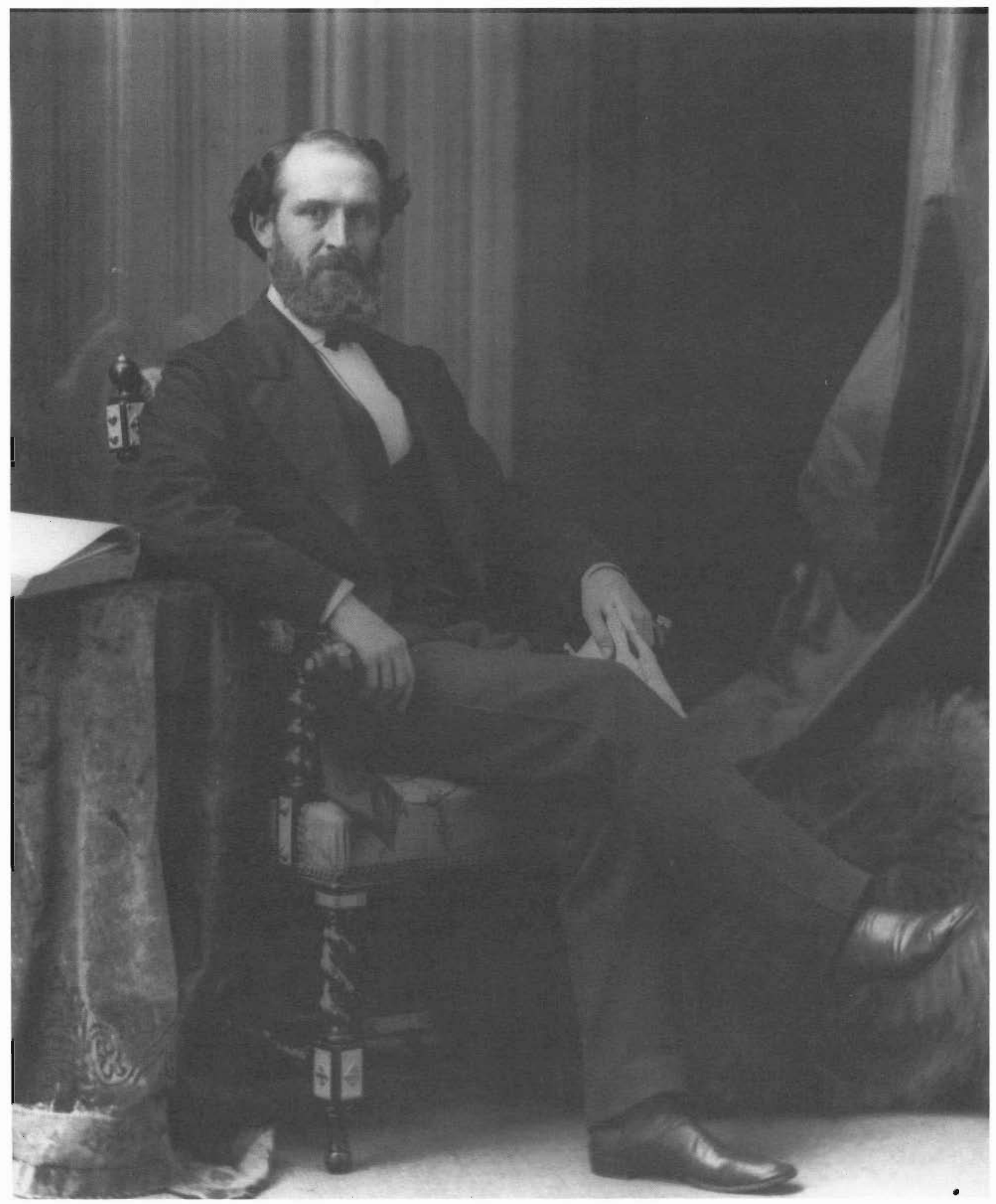

William Macdonald, ca. 1870? (Notman Photographic Archives, McCord Museum of Canadian History) 


\title{
Sir William Macdonald: An Unfinished Portrait
}

\author{
by Stanley Frost and Robert Michel
}

Probably the richest Canadian of his day, tobacco manufacturer Sir William Macdonald (1831-1917) poured much of his fortune into education, mainly in expanding McGill University. Many anecdotes about Macdonald survive but the inner man remains shrouded in mystery. Besides incorporating published information, this article focusses on archival and legal records and attempts to portray Macdonald more broadly than previously done, as a business man as well as a philanthropist and unique figure.

Selon toute probabilité le Canadien le plus riche de son époque, le fabricant de tabac Sir William Macdonald (19311917) a consacré une grande partie de sa fortune à l'éducation et principalement à l'Université McGill. Si l'on connaît beaucoup d'anecdotes sur Macdonald, l'hommen'en reste pas moins entouré de mystère. En plus d'analyser des documents publiés, cet article a puisé dans des dossiers archivistiques et juridiques pour brosser un portrait plus précis de l'homme d'affaires, du philanthrope et d'une personnalité unique.

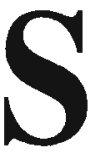

ir William Macdonald (1831-1917) ${ }^{1}$ was a great capitalist turned philanthropist-a Canadian counterpart of Rockefeller, Ford and Carnegie. Unlike most great men of his era, Macdonald must be seen through the eyes of others. $\mathrm{He}$ left educational institutions, buildings and endowments but (apparently) few writings beyond routine business vouchers. Fortunately, this mysterious benefactor who funded both atomic discovery and better crops inspired a wealth of memories and anecdotes. Many of them are recorded in the publications and papers of Professor J.F. Snell, preserved in the McGill University Archives. Snell interviewed and corresponded with Macdonald's family, McGill colleagues and many others, mainly in the 1940 s, when he was writing his carefully researched Macdonald College. ${ }^{2}$ The present authors have tried to examine Macdonald in a new light and in historical context by looking at his tobacco business and by drawing not only on Snell's papers but those of McGill Principal Sir William Dawson and other archival sources. Nevertheless, this is an unfinished, tentative portrait. More about Macdonald remains to be discovered in letters to contemporaries, diaries, business records, and American legal records dealing with his brother Augustine. Such untapped sources might yield a full scale biography of the greatest educational benefactor of his time.

\section{ORIGINS AND YOUTH}

William Christopher Macdonald was born on the tenth day of February, 1831, in Prince Edward Island, the former Ile St. Jean of the French regime. When the British took control of the island after the fall of Louisbourg in 1758, they did not wait for the Treaty of Paris in 1763 before driving out most of the 5000 or so French settlers and encouraging immigration from Britain. As it turned out, the new immigrants came mostly from Scotland and Ireland, with Catholics and Protestants in fairly equal numbers. But political power still resided in the hands of the Crown-grant Protestant landowners. Largely because of absentee landlord neglect, farming was slow to develop. Among the peasantry there was considerable hardship and dissatisfaction, which recognition as a separate Province in 1769 did little to allay. The community was left somewhat unhappy and divided. In his own home, William benefited from his family's degree of affluence and social importance, but outside the home he was early acquainted with rural poverty and lack of educational and cultural opportunities.

Even in his own family, some of the island's tensions were present. William was the third son and sixth child of the Hon. Donald McDonald (1795-1854) and Anna Matilda Brecken. A fourth daughter was born later. Until 1898, William spelled his name "McDonald" like the rest of his family but afterwards he used the spelling "Macdonald", a gesture of some considerable significance, as will become apparent. His 
grandfather, John McDonald (1742-1811), a staunch Catholic, was the last of a line of Scottish chieftains bearing the title Glenaladale. In 1772, because of the continuing harsh treatment suffered by Highlanders after the Stuart risings of 1715 and 1745 , the grandfather transferred his lands to a cousin and transported over 200 of his clansmen to Prince Edward Island, where he had purchased 40,000 acres of land. His own house and estate he named Glenaladale, after his former home. However, before he could organize the settlement efficiently, he was called away to join the British forces engaged in the American War of Independence. During his absence, his estate was ably run by his sister, the redoubtable Helen McDonald but suffering from the twin disabilities of being a woman and a Catholic she could not prevent title to the greater part of her brother's lands falling into the possession of the island's Protestant politicians. After the conclusion of the war, John returned to the task of transforming bis Highland shepherds and cattle drovers into a settled farming community; he only regained possession of his lands after long legal battles. Although the family remained strongly Catholic (John is said to have declined the governorship of Prince Edward Island because he could not accept the spiritual supremacy of the Crown), his son Donald married Anna Brecken, the daughter of a prominent Protestant landowner and Speaker of the provincial House of Assembly.

William grew up therefore in a locally important but religiously divided family. His mother remained Protestant while his father and the children were Catholic. Three of the daughters became Ursuline nuns and William himself as a boy served as an acolyte; his father may have hoped he would become a priest. The remaining daughter, however, converted to her mother's faith. At about his sixteenth birthday, William suddenly renounced Catholicism and, while he did not disavow Christianity, he declared himself free of sectarian loyalties. Whether this renunciation was part of a rebellion against bis father or was caused by a rejection of Catholic practices is unknown; certainly, his subsequent life-long alienation from organized religion strongly influenced his attitudes and actions.

William may have quarrelled with his father over the manner of his education. Unlike his older brothers John and Augustine, who were sent to England to the family's Catholic alma mater, Stonyhurst College,
William went to the Central Academy in Charlottetown. He resented this unequal treatment all the more because he believed himself to be intellectually superior to his brothers. Nor it seems did he appreciate being apprenticed after his schooling to his mother's cousin, who kept a general store in Charlottetown but he may have discovered his interest in business there. Not surprisingly, by the age of eighteen, William had left home; in 1849 he and Augustine were clerking for George H. Gray and Co. in Boston. Soon William began to engage in commerce on his own account. He asked his father for financial backing, failing which he threatened to join the California gold rush. Whether or not his father complied, William raised capital somehow, for in 1851 he persuaded John, his eldest brother, to turn from farming to storekeeping in Charlottetown-William would be the "off-shore" partner. Ambitiously, he declared that now that he had launched his commercial career he would not stop until bis signature was "GOLD wherever it may go". But a shipload of goods to the Island was mostly lost when the vessel was wrecked and the partnership ended.

Meanwhile William and Augustine had moved on from Boston to New York, where they were embarrassed by rumours of debts unpaid in New England-rumours they denied in the newspapers. By 1852 they had moved to Montreal, where William would make his fortune and live the remaining sixty. five years of his life.

\section{THE TOBACCO COMPANY}

In Montreal, William and Augustine set up as oil merchants. Since the petroleum era was a few years in the future, they presumably traded in vegetable, fish or coal oil. At this point Macdonald (as we shall call him hereafter), aged twenty-one, appears to have been cocky and brash-the rising young man incarnate. In a letter of 1852 , he advised his eldest brother John in bombastic terms, far different from his laconic style of later years:

You must assert yourself and push on, let nothing stop you - not even your bald head, ba! ha! ha! If you must loose [sic] all, stop not to grieve, it is unbecoming in a man as well as useless-but stop only to plan, 
continue and devise means to meet your ends. Let your aim next to Heaven be Superiority, let Onward and Upward be your motto-never be second when it is in your power to be first.... Read Franklin's Life-see how he rose from a poor printer boy... to be second only to the immortal Washington-how he persevered in his studies as well as his business-losing no time late or early-not only being industrious but endeavouring to appear so. Study, my dear brother, you require much.... ${ }^{4}$

In 1854, Donald Macdonald visited his sons in Montreal on his way to induct his youngest daughter into the Ursulines in Quebec City. Son and father were quickly reconciled; Donald wrote his son John that the brothers were doing business at the rate of $\$ 40,000$ a year, and reckoned in five years to make half that in profits. Just afterwards, the father died suddenly in Quebec, probably of cholera. So the quarrel of father and son, dear to Greek myth and Victorian novels, resolved itself but without time for a healing sequel.

By 1857 Montreal directories listed the brothers as "importers and general commission merchants," a description covering many activities. They started the tobacco company in 1858 and appear simply as "tobacco manufacturers" from that date. They bought the tobacco in leaf from Kentucky and elsewhere, cured it and processed it. They made chewing and pipe tobacco; the company did not make cigarettes on a large scale until 1922. In 1866 the company was listed as "W.C. McDonald, Tobacco Merchant and Manufacturer"; Augustine had left the partnership. ${ }^{5}$ As early as 1863 he had become involved in cotton trading in the American South. According to Snell, President Lincoln commissioned Augustine to negotiate a secret agreement enabling traders to buy cotton from Southern factors; the cotton would be protected from destruction by either army. Augustine held a large amount of cotton for himself as well as in trust, placing it under the protection of the British flag. However, Union troops burned his cotton in January 1865. Augustine won compensation after the Civil War. He later clashed with his lawyers, suffered legal reverses, faced charges of contempt of court and appears to have been imprisoned in New York between 1879 and 1885. Relations between William and Augustine during those years are unknown. Snell suggested that the brothers may have fallen out by the mid-1860s. As of 1895, Augustine appears to have been living in New York City; his story may be as fascinating as his brother's. ${ }^{6}$

His first seventeen years in Montreal, William Macdonald boarded at hotels. By 1868 the handsome bachelor of thirty-seven had still no intention or prospect of marriage. Yet he yearned for a stabler domestic life and in August 1868 he invited his mother and sister Helen, to come and keep house for him. Characteristically making a carefully detailed proposition, he listed the advantages of living together, and promised gas lighting (a very modern convenience), hot and cold running water, servants, covered and open carriages and sleighs, and (knowing their religious concerns) the proximity of churches. ${ }^{7}$ For Helen and her mother the proposal must have sounded attractive indeed. In 1869 the three Macdonalds moved into a townhouse, No. 3, Prince of Wales Terrace, facing Sherbrooke Street and at that time Montreal's most upto-date housing development. This domestic menage was to continue comfortably for twenty years, until both his mother and sister died. Fatefully, the Macdonald home stood almost next door to McGill University.

Macdonald's first tobacco factory was at 163 Water Street in Montreal (see colour illustration p. 81). The business grew quickly. By 1871 his factory employed 500 hands and Macdonald was reputed to be a millionaire. Women and adolescents, hired cheaply, made up at least half the work force at Macdonald's as at other tobacco makers. They did much of the preliminary work: stripping, sorting, and drying the tobacco plants. From the outset, Macdonald exploited a popular product; he had a secret recipe, probably molasses-based, to sweeten his chewing tobacco. He had an eye for marketing; his tobacco plugs came with a distinctive heart-shaped label made of tin, pressed into the tobacco, bearing the catching motto "the tobacco with a heart". In the mid-1860s, Macdonald appears to have been producing eleven brands of tobacco products, according to the advertisements of Forester Moir and Co. who acted as his agents. Macdonald does not appear to have made cigars-at least he was not listed among cigar makers by the Labour Commission of 1888. Outdoorsmen across the expanding country liked Macdonald's plugs; trappers, Indians and Inuit all recognized the heart-shaped label. 


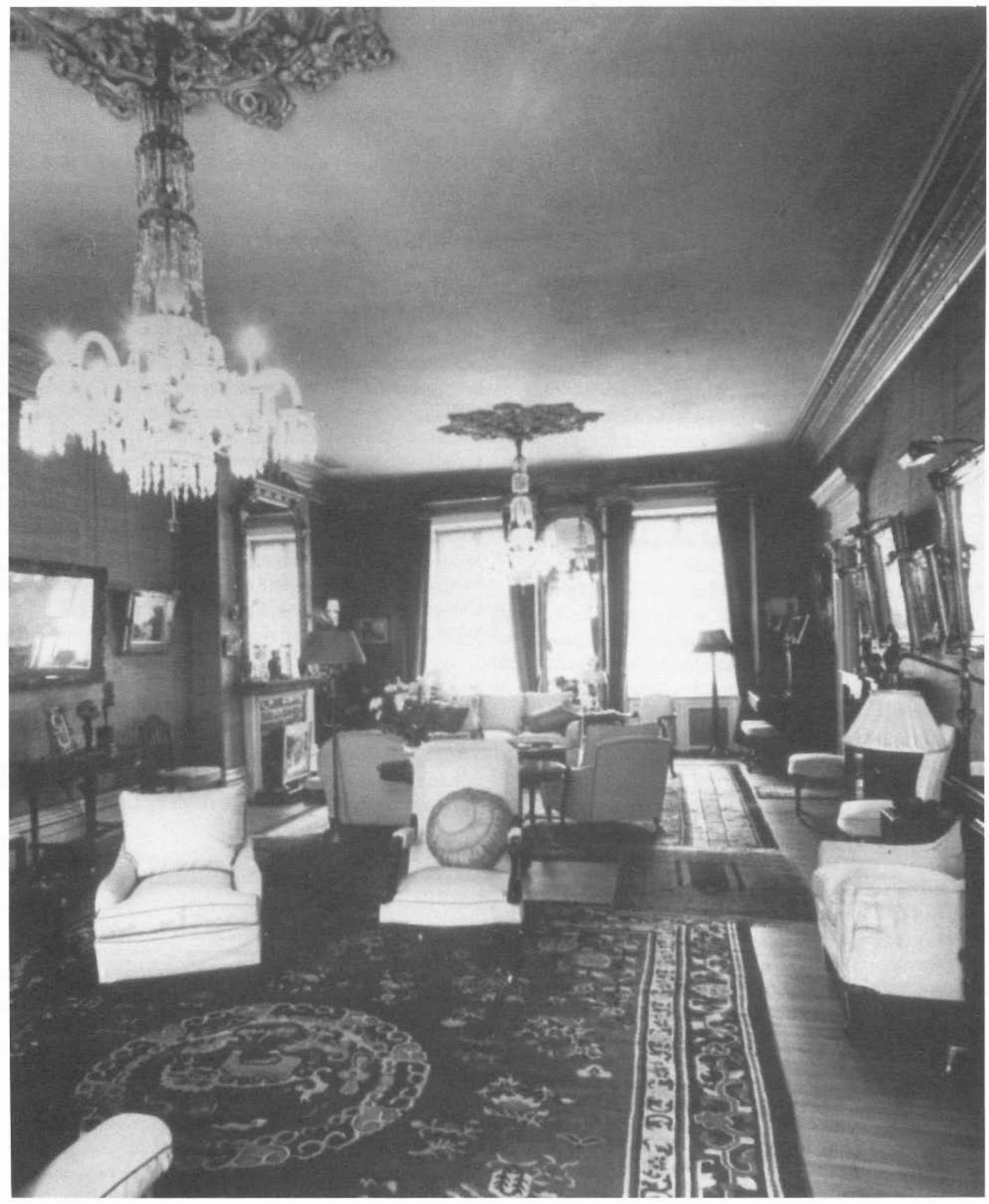

Living Room, Macdonald's house in Prince of Wales Terrace, n.d. (Photographer is probably Notman) 


\section{Sir William Macdonald: An Unfinished Portrait}

As industrialization increased, Montreal became an important centre for manufacturing chewing and pipe tobacco as well as cigars. According to Bettina Bradbury, the number of Montreal tobacco workers grew from about 1000 in 1871 to about 3000 by 1891 . Canadian cultivation of tobacco also increased. In 18701871 Quebec produced $542,208 \mathrm{~kg}$ of tobacco while Ontario produced $181,381 \mathrm{~kg}$. By 1910 Canadian production reached $7,938,000 \mathrm{~kg}$, with Quebec still the greater producer. In the 1860 s and 1870 s, Macdonald actively ran his own business. Ironically, he disliked the use of tobacco, but was said to have prided himself on a good nose and feel for a leaf. ${ }^{8}$

In 1875 Macdonald built a new tobacco factory, the largest in Canada, in east Montreal on Ontario Street at Iberville Street. The factory still operates (as RJRMacdonald), its old brick recently covered by modern siding. Almost nothing was published about the company. As sole owner Macdonald owed no reports to shareholders. He and his managers, however, gave detailed information about the company on at least two occasions-in testimony to the Labour Commission in 1888 and after a fire in 1895. Running the company with only a few assistants, Macdonald kept administrative and overhead costs to the bare minimum, with a wide profit margin as the result. He kept the ratio of office to production workers incredibly low-perhaps 1 to 200 . He avoided all unnecessary expense, including impressive offices, correspondence and costly advertising. Customers had to produce cash or a certified cheque for their last consignment of goods before any new order would be accepted. The authorized order form then would be taken to the Custom House for payment of charges and, after being stamped, to Macdonald's warehouse to take delivery of the goods. Customers also had to arrange transportation to their own premises. Macdonald had no wish to impress; he loved the utilitarian. For forty years he operated out of a small, notoriously plain office on Notre Dame Street two miles away from his factory. Finally, in 1910, nearing eighty, he moved to an office on the seventh floor of the Guardian Building on St. James St. and conceded to taking the elevator.

In February 1888 in Montreal, Macdonald and many other manufacturers and employees testified before the Royal Commission on the Relations of Labor and Capital in Canada. ${ }^{9}$ The Commission had been set up to investigate female and child labour, morals, sanitary conditions, fire and other hazards, wages, hours of work, treatment of employees, exercise of monopolies, activities of unions, and compliance with Factory Laws. Current law allowed girls of fourteen and boys of twelve to work in factories; however, witnesses testified that numerous boys and girls as young as ten worked in the Montreal tobacco and cigar factories. "Sweating" or payment by the piece was legal in Quebec. Tobacco workers' wages were regularly reduced in winter on the grounds that there was a seasonal surplus of hands.

Macdonald Tobacco was run by a superintendent, Samuel Wells, and about a dozen foremen. There were about 180 sub-contractors or bench-hands, each of whom could recruit three or four workers, often women or children, as stumpers, stringers and coverers. In all, Macdonald employed about 1100 hands, a slight majority being female. Most were aged fifteen to twenty-five. Macdonald's testimony on 24 Feb. 1888 offers a unique chance to hear his own words-if only a similar transcript existed for his quiet announcements of his great educational projects! By this date, his trusted assistant David Stewart dealt with daily business; Macdonald did not appear to be involved in the direct management of the factory. When the Commission pressed for information about child labour, legal and illegal, Macdonald could not say how many boys or men were on his payroll. Questioned if the factory employed children under twelve, he replied: "Not knowingly. We are greatly deceived about the children....a person can deceive or mistake the age of children and I may say they are sometimes brought in surreptitiously under age by those occupying benches". Asked if he was familiar with the details of the work in the factory, he answered, "To a certain extent. I do not attend so closely to it as I used to do, but I understand the whole of the operation thoroughly. ${ }^{\prime 10}$

The commission enquired whether the trade practice of reducing wages in winter was hard on the workers or not. He replied: "That will depend upon how they provide for rainy days. When they have good wages they should save for the short period." Asked if he got much competition from American manufacturers, he replied proudly, "Well, we can scarcely call it competition. There is a certain amount imported....It is very small." When a commissioner suggested he could pay higher wages than his competitors, he observed: 


\section{Sir William Macdonald: An Unfinished Portrait}

I have to follow the course of the labour market, and if I pay more wages than other competitors, I have that much disadvantage, and in the course of years I may dry up. I have to have sufficient business ability to run my factory, which, I need hardly explain, is run solely on business principles ....it is a matter of supply and demand.

The chairman prompted: "You do not work for charity?" Reply: "I do not, sir. I am in business for the purpose of business." "For the purpose of making money?" "Yes." A less friendly commissioner asked if he had considered any system to let the employees share in the profits. The $\$ 200,000$ he paid them was part of the profits, Macdonald observed. "You must have considered doing more", pressed his questioner. "I have," declared Macdonald, "and I have really been very desirous to do it, but cannot see how it is going to be brought about with any degree of safety to the capitalist." He pointed out that he sometimes gave bonuses, as a matter of choice, when he could afford it.

Macdonald's factory appears to have been fairly run by the standards of the time. It resembled other tobacco factories as to hours, wages, and the employment of children under twelve (deliberate or unknowing). Like others, it fined employees for minor infractions; however the fines were given to charity. And unlike some cigar factories, Macdonald's company did not have to defend itself from charges of poor sanitation, tolerance of immorality, unseparated toilets, or corporal punishment (one cigar maker was accused of beating young women employees). Like other manufacturers, Macdonald defended the capitalist's right to run his business as he pleased within the law. He evidently separated his imaginative gift-giving from his business operations; he saw no contradiction between working his French-speaking urban employees at market pay rates and giving his profits away as he saw fit to benefit English speaking youth.

Significantly, Macdonald's testimony shows that by 1888 he had lost interest in the daily working of his company and valued it only as a source of wealth to be used for higher purposes. His often-expressed dislike of his company's product may have impelled his philanthropy. Macdonald College Principal Francis C. Harrison once asked to see the factory which had paid for the College. Macdonald refused, replying: "I am not proud of my business, and that feeling, perhaps, has been the reason for my donations. "11

In late 1894 and in April 1895 Macdonald, went through traumatic experiences; his domestic life was upset and his factory burned half way down. Not long after, he suffered a serious fall from his horse. Approaching old age he must have felt lonely and vulnerable; perhaps he found refuge in the tidal wave of philanthropy with which he practically refounded McGill.

Testimony about the fire reveals the care with which Macdonald had built his factory. On 25 April 1895, fire broke out by accident in a drying room at the factory. The two upper floors of the four story brick structure burned out. At the time, about 800 to 900 people were employed. The supervisors tried to keep the evacuation orderly but many workers panicked and three women and one man died. The fire and individual escapes and tragedies were documented by Montreal newspapers over the following two weeks. ${ }^{12}$

The fire highlighted the French-English, religious, and economic division of Montreal. The workers were mostly French-speaking Catholics from the east-end Montreal district in which the factory stood. The owner, managers, and several supervisors were English-speaking Protestants. The French language newspapers hinted, politely enough, that while Macdonald earned his fortunes with French Canadian labour he gave his charity mainly to English Protestant institutions. La Presse criticised the fire precautions and behaviour of supervisors during the fire more closely than did the English newspapers. A committee of city aldermen looked into the safety precautions and determined that there had been no negligence or wrongdoing by Macdonald or his supervisors. Not surprisingly, the French Canadian aldermen were more critical of the fire escape system than the English members.

Although the factory had a water supply and hoses for fighting fire, and the various supervisors, including David Stewart's son Howard (who with his brother Walter worked for Macdonald) managed the evacuation courageously, there was confusion as well as delay in ordering workers to leave the upper floors, and some 

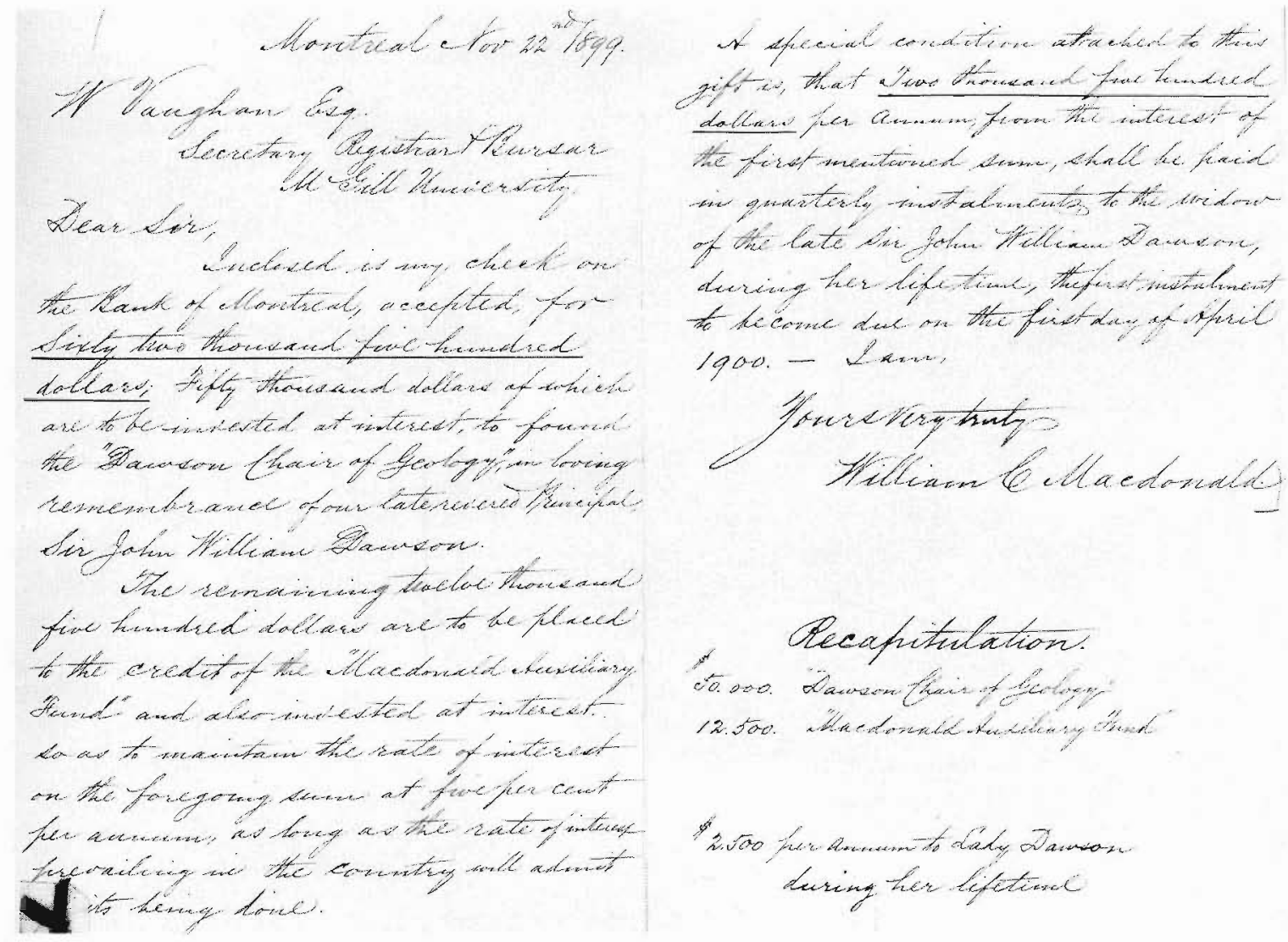

Macdonald's letter creating the Dawson Professorship of Geology, 22 Nov. 1899. (McGill University Archives)

panic among the workers, mainly women. At the Coroner's inquest into the deaths of the workers, Macdonald testified that his building had been carefully designed and equipped to defend itself against fire and had passed the city inspection of factories. However, the Coroner's jury found that the company had not sufficiently drilled staff to work the fire apparatus, leaving Macdonald open to civil lawsuits for damages by relatives of the deceased workers. A representative of the Knights of Labor, John Brennan, attended the inquest; whether some of Macdonald's workers belonged to or planned a union is unclear.

Macdonald voluntarily gave pensions to some of those injured in the fire. One of three sisters employed at the factory, Alphonsine Thibaudeau, had died in the fire. In 1897 her parents sued Macdonald and were awarded \$1999. ${ }^{13}$ Macdonald's appeal in Queen's Bench dates from 1899. ${ }^{14}$ The testimony taken in 1897 provides much information about the factory.
Macdonald was represented in 1897 by Donald McMaster, Q.C. and the case heard by Justice Pagnuelo (incidentally, a former critic of McGill's Law Faculty, which had benefitted from Macdonald's philanthropy) on 11 January 1897..5 Finding against Macdonald, Pagnuelo had judged that the supervisors had delayed too long in raising the alarm and that the foreman had erred by preventing the women from leaving immediately by the central tower stairway.

Macdonald's defense had pleaded that escape facilities were adequate, warning had been raised in proper time and that Alphonsine Thibaudeau had escaped from the burning factory and then recklessly re-entered it to look for her sisters, panicked, and thrown herself from a window. Macdonald had feared fire when he had built the factory in 1875. The factory's architect Alexander Hutchison ${ }^{16}$ (who would later design Macdonald College) testified that Macdonald had been "most anxious to have a 
thoroughly safe building"; he had encouraged Hutchison to introduce a new method of slowing the spread of fire by isolating important beams with plaster of Paris. ${ }^{17}$ The factory had been built in brick and wood to the best slow burning standards, with the special feature of a wide staircase in a central tower, meant to serve as a fire escape.

These farsighted precautions undoubtedly saved lives but the legal issues were whether the evacuation had been properly managed and whether Alphonsine had escaped and then gone back. Much testimony revolved around the similar dress and appearance of the ill-fated Alphonsine and her sister Hermina and which of the two had been identified by witnesses as among those who had escaped the building. The transcript becomes not just a detective story but a tragedy as Alphonsine and her sister Maria are described pressed against the grilled windows, trying to breathe, saying their acts of contrition. ${ }^{18}$ The outcome of Macdonald's appeal has not yet been determined.

The fire and lawsuits may have reinforced Macdonald's detachment from his business and confirmed his ambition to become the nation's outstanding benefactor. Although losses from the fire amounted to about $\$ 500,000$, Macdonald rebuilt at once and business quickly recovered. According to the press, Macdonald's business for many years was worth $\$ 10,000,000$ and made profits of $\$ 750,000$ per year. Although he had lost interest in running his company, he could not bring himself to sell it-at least not to a disliked rival. In 1904 he was offered $\$ 6,500,000$. At first he entertained the offer, but only to find out who the real principals were. The moment he suspected the offer came from the American Tobacco Company, he stopped the negotiations. ${ }^{19}$ Only in his eighties did Macdonald lose some of his energy and strength. He remarked in about 1912 that he was used up in "mind, body and estate." When his right hand man, David Stewart, suffered a stroke in 1914 , he seems to have had little more to do with his business. ${ }^{20}$

\section{BENEFACTOR OF MCGILL}

How Macdonald first became interested in McGill might inspire today's hard pressed fund raisers, once again relying on private wealth. As mentioned earlier,
Macdonald and his mother and sister had lived next to the campus since 1869; thus he would have had every opportunity to become McGill-conscious. According to one story, Macdonald became interested in McGill when student canvassers for a financial campaign boldly visited him at his office. ${ }^{21}$ Another story recalled a meeting of friends of McGill at the Fraser Institute around 1870 . "Away in a back seat, looking as if his greatest desire in life was to escape observation, sat Mr. William C. Macdonald.... reported to be enormously rich." After McGill's needs had been aired, the chairman approached Principal Dawson:

...do you see that gentleman sitting on one of the back benches near the door... That is Mr. William Macdonald, the wealthy tobacconist. If you could only interest him in the University there is no telling what he might do for it. Acting upon this hint the man of education asked to be introduced to the man of wealth. Dr. Dawson appealed with such effect to Mr. Macdonald, that the heart of the millionaire warmed and his purse opened. ${ }^{22}$

Whatever the cause, the records confirm that by the late 1860 s Macdonald took his first tentative steps as educational benefactor. McGill was just beginning to emerge into local and provincial prominence under Dawson's vigorous leadership. Macdonald and Dawson quickly became natural allies; both distrusted Roman Catholicism and both favoured practical, scientific educational programs, Indeed, Dawson's first publication had been a slim textbook on "agricultural chemistry". Macdonald, free of the dynastic ambitions, social preoccupations and art collecting passions of his fellow Montreal millionaires, found his life's mission in promoting his educational ideas. In the process, he was to transform McGill from a medical school-cum-arts college into a full scale university with particular strengths in the new expanding fields of science.

The McGill Governors' minutes from 1866 onward document the University's strategy of raising funds from the Montreal English business elite for endowments and operating costs. Petitions to the provincial government and the crown had failed to win funding. Under Dawson, McGill had become viableand visible as the anchor of the fashionable "Golden 
Sir William Macdonald: An Unfinished Portrait

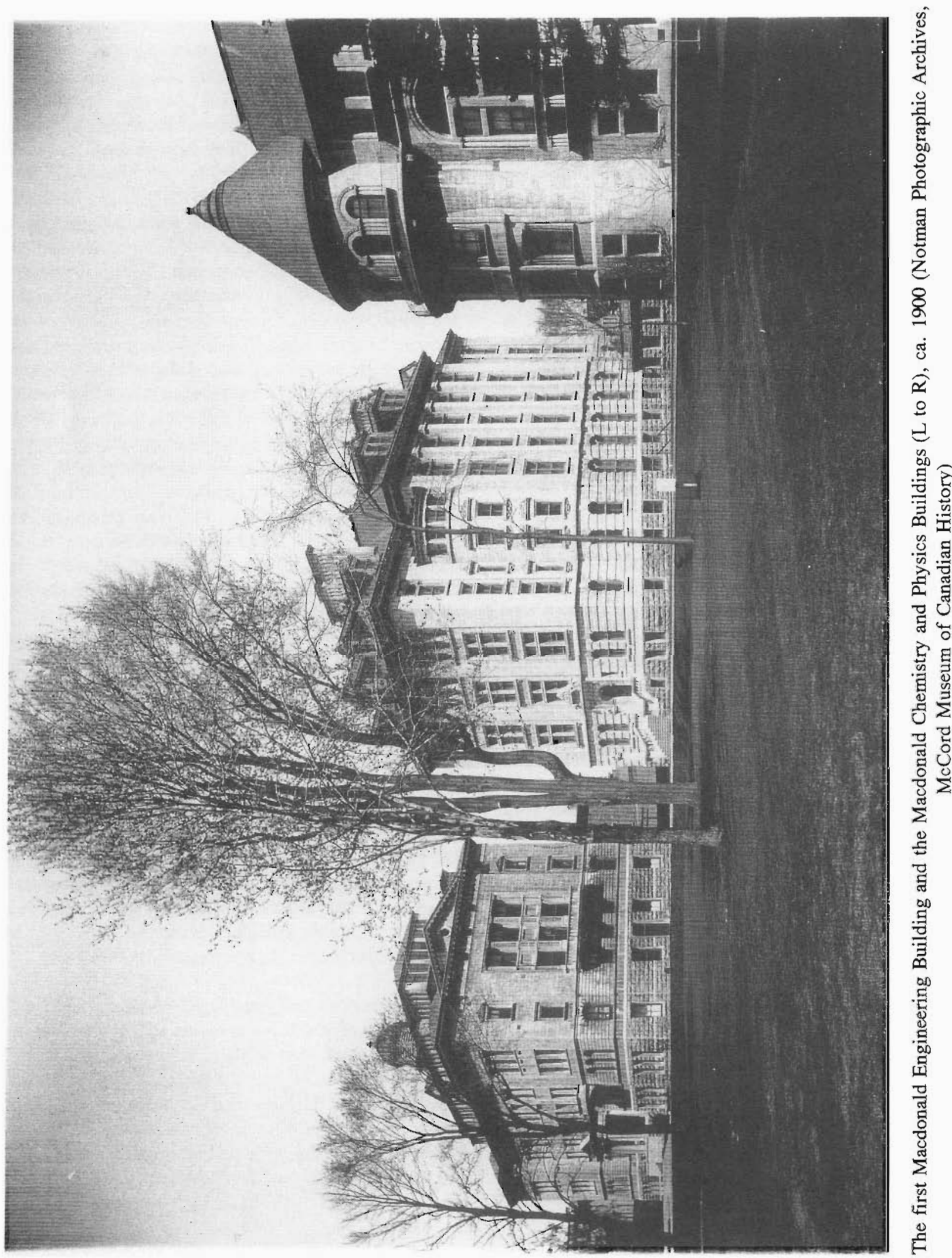




\section{Sir William Macdonald: An Unfinished Portrait}

Mile" district, just being built. Perhaps inspired by the unifying spirit of Confederation in 1867 and the new Dominion's need for national institutions, such wealthy Montrealers as Peter Redpath and Donald Smith (later Lord Strathcona) joined James Ferrier, J.H.R. Molson, and Sir Francis Hincks in supporting McGill. They served on the Board and used their financial expertise on the Estate Committee which handled property sales, rentals and the other few sources of revenue. By 1868 Macdonald joined this group of wealthy, largely Scots descended businessmen supporting McGill. He gave instruments, endowed scholarships, and in 1870 along with William Molson, Thomas Workman, and John Frothingham each gave $\$ 5000$ for the General Endowment but lagged behind Redpath, the leading benefactor of the $1870 \mathrm{~s}$ and $80 \mathrm{~s}$, who gave $\$ 20,000$ to endow a Chair of Natural Philosophy. ${ }^{23}$ Redpath and Macdonald brought similar concerns to their philanthropy: neither had children and so diverted their wealth to charity; both became interested in McGill around Confederation; and both (following Dawson's lead) supported education in the scientific and practical subjects the young country needed rather than classics or philosophy. ${ }^{24}$

In the early stages of his educational philanthropy, Macdonald relied on Dawson to decide the best use of his charity. Writing to Dawson in March 1870 regarding his scholarships, Macdonald declared: "I shall be content with any distribution of them you may make, satisfied that it will be for the greatest good. Education being your specialty, your judgement in all such matters will be superior to mine. "25 By 1885 , keenly involved in educational philanthropy, Macdonald had firmer ideas. Responding, apparently, to Dawson's suggestion that some of his scholarships be diverted to the newly admitted women students, he replied:

With regard to the Scholarships, my preference would be not to make any changes. It appears to me that to transfer any of the existing Scholarships to the "Womens department" would be likely to shut off contributions, that in all probability, would be made towards supplying that aid to the Womens classes when the public became aware that such was required. The new department will be a fresh attraction to the generously inclined and the pupils more likely to be effective in securing attention in that way, if the opportunity is given them... ${ }^{26}$

Here he showed a canny sense of fund raising as well, perhaps, as his feeling that women students were Donald Smith's territory.

By the $1890 \mathrm{~s}$, after twenty years of steady gift giving, Macdonald plunged wholeheartedly into his educational vocation and surpassed Redpath and Smith. In the decade of the nineties, for three major disciplines, Physics, Engineering, and Chemistry with Mining, he gave whole buildings, fully equipped and staffed by professors in endowed chairs, and funded by their own operational endowments. He had a committee of management appointed for each building, which included the department head, the Principal, the Bursar, another member of the Board and himself. The committees oversaw expenditures and Macdonald required close accounting. He was proud of the research done in his laboratories. When the Royal Society awarded Rutherford the Rumford medal, he gave a university dinner in his honour but modestly did not attend himself.

But he knew better than to confine his benefactions to the sciences alone. During his fifty year association with McGill, he gave substantial grants to other disciplines, including Arts, Law, Education, Architecture, Music, and by bequest a major gift to Medicine, an area he had previously left to the generosity of his fellow Governor and rival benefactor, Smith-Strathcona. It is particularly noteworthy that over the years he donated some 10,000 books, all in designated subject areas and many of them individually chosen, to the university library. Macdonald had educated himself through wide-ranging reading to become a discriminating and knowledgeable giver.

These benefactions greatly enlarged the campus with distinctive greystone buildings designed by Andrew Taylor, an architect whose professional skills and business methods Macdonald had carefully vetted and approved. The Physics and Engineering buildings opened in 1893, the Chemistry and Mining Building in 1898. When the Engineering building burned in 1907, Macdonald immediately funded its replacement. 
Macdonald's interest in McGill led to friendship with the Dawsons and their son-in-law, Chemistry Professor Bernard Harrington. Dawson and Harrington quietly nudged their campus neighbour to support science buildings, laboratories, and professorships. In July 1891 Harrington wrote his wife Anna (Dawson's daughter) that Macdonald had as good as told him he had a chemistry building in view and might combine it with a mining building. Macdonald planned such gifts carefully, taking bis time. In June 1896 he took Harrington and the architect Taylor on an inspection tour of American chemistry buildings. Now things moved quickly. Harrington wrote Anna in July 1896 that Macdonald came to see him and Taylor "and went over the details of each floor most carefully. Evidently he is just longing to see the walls go up. He walked home with me and this morning I breakfasted with him. " 27 Macdonald enjoyed participating in the family lives of the Dawsons and Harringtons; he called after the births of all nine Harrington children, predicting one girl would become a judge. He declared that Lady Dawson was "more than half of the University", as she administered many of its social functions. On her fiftieth wedding anniversary, he gave her a pendant of diamonds and pearls. He also may have visited the Harrington's cottage at Little Metis. ${ }^{28}$

After retiring as Principal, Dawson sought Macdonald's support for his incoming successor William Peterson and pushed liberal rather than professional education as the University's highest function. Writing in August 1895, he hoped that Macdonald and the other Governors would give Peterson

a free hand in his work. The Principal of a University like the General of an army, should not be too much controlled by the government he serves, else he will have small chance of being victorious. Even small things may determine the loss of great battles, and only the man who is actually superintending the fight can know what their effect will be.

Dawson added that the needs of the arts and sciences had been neglected relative to the professional faculties and broadly hinted how Macdonald might help:
Quite a large sum might now be profitably employed in augmentation of staff... introducing advanced courses of study and other improvements that would give a new impetus to the faculty of Arts, not to speak of enlargement of its class-rooms and other accommodation. ${ }^{29}$

As Dawson hoped, Macdonald continued to support the arts, which included science as well. Dawson sent Macdonald his writings, including a copy of Eden Won and Lost (1896) which aimed to reconcile scripture with nature and human history. Macdonald replied cautiously that he hoped to be "interested and instructed" in reading it. ${ }^{30}$

Dawson died on 19 November 1899; within three days Macdonald sent a cheque for $\$ 62,500$ to McGill Bursar Walter Vaughan, establishing the Dawson Chair of Geology, with the provision that the interest $(\$ 2,500$ per year) be paid to Lady Dawson for life. ${ }^{31}$ In this way Macdonald both memorialized his mentor in educational benefaction and tactfully helped Lady Dawson. Anna Dawson Harrington wrote her brother Rankine that Macdonald's gift would make their mother "thoroughly comfortable \& is a great blessing". ${ }^{32}$ The incident illustrates Macdonald's style of quiet, graceful giving and the symbiotic relation between wealth and education personified by Macdonald and the Dawson-Harrington family.

Where his university was concerned, Macdonald was both foreseeing and protective. He provided for future expansion by purchasing and donating twenty-five acres of land on the lower slopes of the mountain, above James McGill's original farm. In so doing, he restored the campus to the size of the McGill bequest. A few years earlier, he bad stopped a syndicate from building the Ritz-Carleton Hotel on the southwest corner of the campus; he told the speculators to sell the land to him at $\$ 500$ profit or he would ruin them all. Then he gave the site to McGill, saying he would not have his university become the backyard of an hotel. McLennan Library stands there now. Although he led an austere life himself, he built a splendidly equipped Student Union for the male students, undoubtedly motivated in part by the fact that his friendly rival in philantbropy, Lord Strathcona, had already provided the lavishly furnished Royal Victoria College for the women. 
Macdonald's gifts and bequests to McGill were to exceed $\$ 13,000,000$, a largesse then unparalled in Canada or any other country. ${ }^{33}$

\section{RURAL EDUCATION AND MACDONALD COLLEGE}

Mindful of his own rural background and still resentful that his own education had been skimped, Macdonald became interested in rural education in the late 1880 s, after he was elected to the board of the Bank of Montreal. ${ }^{34}$ In the Bank's reports, he read of the success of the pioneering educational efforts of James W. Robertson, a school teacher who was to become a member of the staff (1890-1895) of the Dominion Experimental Farms outside Ottawa and later Commissioner of Agriculture and Dairying (18951904). Robertson interested Macdonald in simple schemes to improve field crops (for example, be offered small prizes to school children for the biggest heads of their fathers' grains) and to encourage "practical" education-carpentry and gardening - in rural elementary schools. The Macdonald Rural Training Fund was established in 1899 to contribute (in at least one year as much as $\$ 40,000$ ) to the procurement and payment for three years of specialist teachers in various locations in eastern Canada, including Prince Edward Island, on condition that normal funding would continue the program thereafter. But since Macdonald's concern was with Englishspeaking, rural populations, which typically were widely scattered across a countryside, the scheme was re-oriented towards the consolidation of small rural schools into one larger, central school where "practical" training could be a regular part of the curriculum. The Macdonald Fund would provide for the building of the new schools and their operation for three years, after which, again, it was presumed that traditional funding would take over. In the five eastern provinces, as late as 1907, schools initiated by the Fund, and other consolidated schools organized independently but assisted by it, were continuing to receive help and demonstrating their value.

Yet another initiative which attracted Macdonald's attention was that of Adelaide Hoodless in Ontario. Hoodless had founded the rural Women's Institute movement, and by 1891 was promoting training classes in household management through the Young Women's Christian Association in Hamilton, Ontario. In 1900, largely through her efforts, a Normal School of Domestic Science and Art was established. In 1903 the School was moved to become part of the Ontario Agricultural College and, with a broader curriculum designed specifically for rural students, renamed the Macdonald Institute. The building was provided by the Macdonald Fund, together with a residence for the women students. The Ontario government undertook to operate the buildings and supply the teaching staff.

This venture inspired William Macdonald's major educational experiment. He conceived the idea of a rural education college which would provide practical instruction for young people who would live and work in English-language rural communities in Quebec and the nearer parts of Eastern Canada. Macdonald had no animus against their francophone counterparts, either in Quebec or New Brunswick, but his interest, born of his P.E.I. upbringing, was firmly in English-speaking rural society. He designed his college to be a truly rural institution giving practical instruction for future farmers, farmers' wives and the teachers of farmers' children. So, it had three divisions, Agriculture, Domestic Economy, and Teacher Training. Macdonald intended to build it at Ormstown, Quebec, but when site and transportation difficulties arose, the location was changed to Ste. Anne de Bellevue, at the western end of Montreal island. He intended the College to be fully independent of any government or academic control. However, by 1906 Macdonald had already enjoyed some thirty-five years of benevolent association with McGill University, and had established a cordial relationship with his next-door neighbour on Prince of Wales Terrace, William Peterson, Dawson's successor as principal. Peterson persuaded him to modify his intention and to name the University's Board of Governors as the governing body of the new college. To increase the viability of the project, the University agreed to move the McGill Normal School for Teachers out to St. Anne's, as a constituent part of the program. This move turned out to be extremely important, for the agricultural and domestic economy programs had at first only limited appeal. Macdonald not only provided all the buildings (designed to conform with the founder's ideas by Hutchison and Wood) but he also endowed them with a capital fund of $\$ 2,000,000$. The Macdonald College opened in 1907 with 115 teachers 


\section{Sir William Macdonald: An Unfinished Portrait}

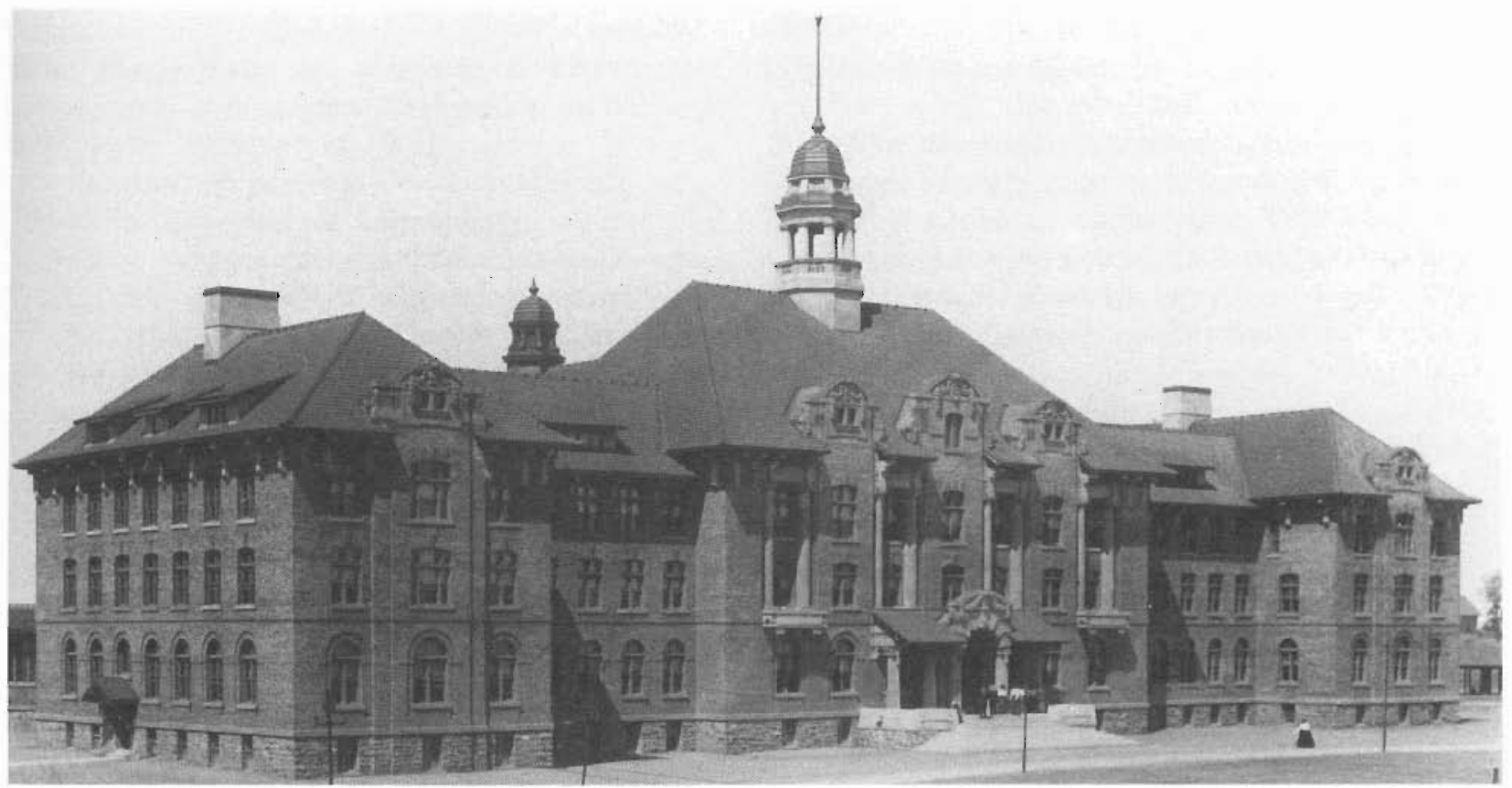

Macdonald College, Main Building, ca. 1910? (Photographer unknown, McGill University Archives)

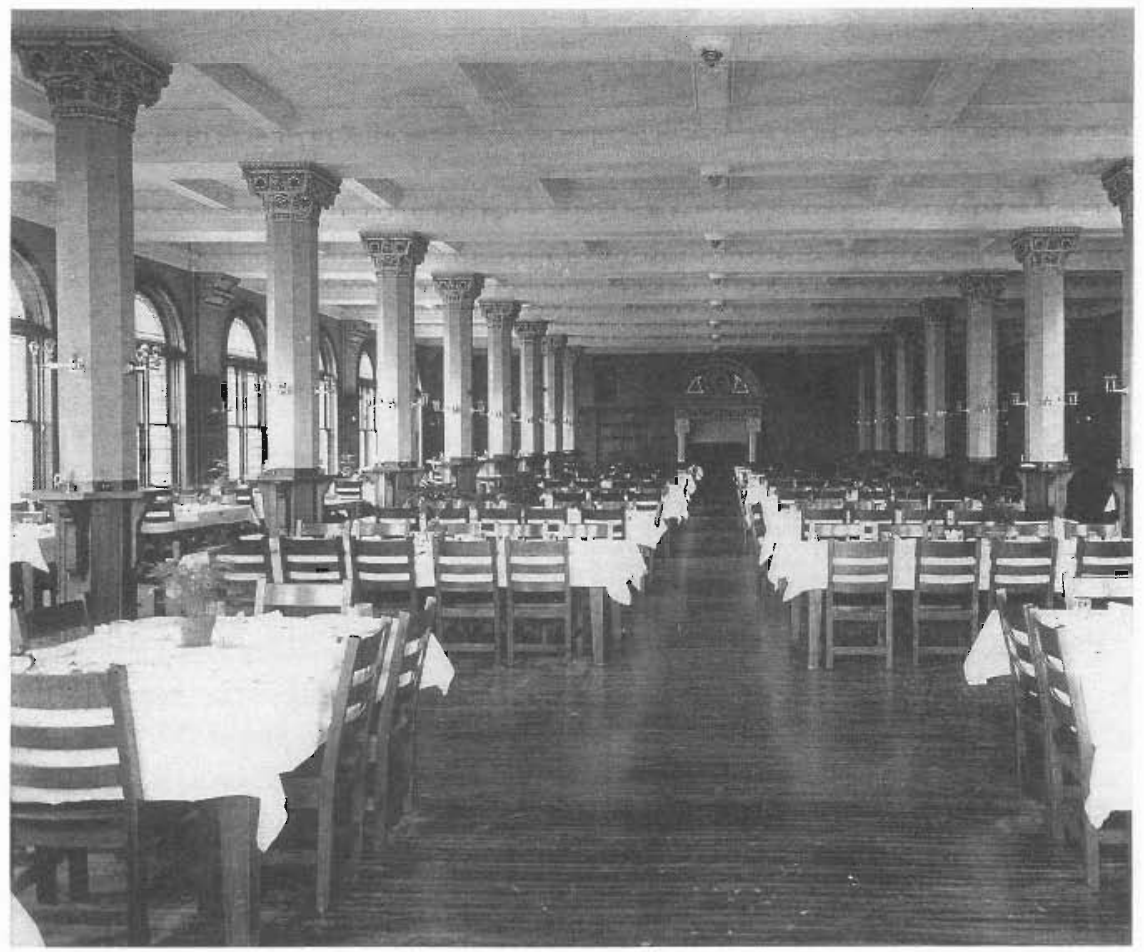

Macdonald College Dining Room, ca. 1910? (Photographer unknown, McGill University Archives) 


\section{Sir William Macdonald: An Unfinished Portrait}

in training, 62 students in household science and 38 in Agriculture. There were 37 members of staff, and J.W. Robertson was the first principal. Since 1907 the College has formed a strong, integral part of McGill University. Macdonald paid many visits of inspection, during and after construction; he even watched the chickens lay eggs. The tobacco company had orders to supply the college regularly with tobacco ashes for fertilizer and insecticide experiments. ${ }^{35}$

\section{LATER LIFE}

While Macdonald's business and philanthropy are well documented, relatively little is known about his private life. In family affairs, Macdonald found both contentment and conflict. Only one of Macdonald's six brothers and sisters married: in 1866 the eldest, John Archibald, then forty married a girl of eighteen. William Macdonald paid for some of the education of the nine children. He also paid for improvements at Glenaladale, the family farm in Prince Edward Island. Macdonald's mother died in 1877 and his sister Helen died in 1889 on a trip to Italy. Soon afterwards his eldest niece, Anna Rebecca, came to keep house for him. Against his wishes, however, she left his home to marry a distant, Catholic relative, Alain Chartier Macdonald on 29 November 1894.

Anna's defiance of her uncle's wishes may have scandalized Montreal's English-speaking society, although no one could deny her right to marry as she chose. B.J. Harrington wrote his wife the news:

"If you have not heard of it already you will be surprised to know that Anna McD. has been married to that fellow who has been running after her so long. He went down to P. Ed. Id. [Prince Edward Island-home of Anna McDonald's family] and they were married by an R.C. priest! Fancy Mr. W. C's feelings. I am told that he knew nothing about it until the whole thing was over. She has not a home of her own, but is living with his mother and sisters. $^{36}$

Macdonald cast her off, refusing to speak to her; his family had failed him for the last time. He could adopt thousands of young people through charity; he could not accept what he probably saw as disloyalty in his immediate clan. As Snell writes,

The separation was absolute, the uncle not only refusing to admit his niece to his house but also discontinuing all assistance to his brother's family. It was only on his deathbed when, unable to speak, he affectionately pressed her hand, that the breach with his niece was closed... There can be no doubt that this separation from his beloved niece cost the sixty-three year old uncle an agony of spirit similar to that suffered by the adolescent youth when incompatible loyalties separated him from his father. Servants present in the house after the young lady's departure tell of his pacing the floor in a passion of resentment and grief. ${ }^{37}$

Fifty years later, Snell contacted the niece, now Anna Walsh. Disinherited, she bore no grudges. She told Snell: "I still have a feeling of disloyalty to my Uncle....He suffered much-\& had great disappointments. ${ }^{138}$ She added to the story in a letter of 16 Sept. 1943:

You asked why my Uncle should have objected to my marriage with Alain. This is a question I often asked him,- -his answer invariably being "I do not wish it." My father \& Mother, Brothers \& Sisters all loved Alain—\& there was nothing in his character but what was kind $\&$ loveable.... ${ }^{39}$

Macdonald probably disliked losing his last close relative and housekeeper. Suggesting that Macdonald saw the marriage as his final failure to turn his family away from Catholicism, Snell attributed Macdonald's estrangements from his relatives to "a determined adherence to principle or set policy which cost him much agony of spirit. "40 Once he had taken a decision on a personal, business or charitable issue, he seldom changed his mind.

It was an unhappy time for Macdonald. A few months later, in April 1895, his factory burned and in September, as B.J. Harrington reported, "his horse 
stumbled and fell, throwing him heavily upon the road. "41 $\mathrm{He}$ was laid up some days and when his injuries healed he may have found solace in planning the Chemistry Building with Harrington.

In 1898 Macdonald reluctantly accepted a knighthood. From that time on, he signed his name "Macdonald". The change in spelling had obvious motivations: he disliked the product on which his name appeared and with the defection of his niece he had cut off his family. In 1914 he followed Strathcona as Chancellor of McGill. David Stewart was stricken with paralysis on 11 March 1914; his sons Howard and Walter would now run the business. By this time Macdonald's own health was failing. $\mathrm{He}$ took occasional drives around the campus but was confined to his bed for the last six months of his life. He died peacefully on 9 June 1917; the obituaries recited the quaint stories that clung to him and declared him Canada's greatest benefactor.

His neighbour for twenty-one years, Principal Peterson eulogized him at a simple gathering in Macdonald's house. Avoiding platitudes, Peterson tried to express what had made Macdonald so remarkable:

Anything that savours of eulogy would have been distasteful to him. You know how modest he was, with a kind of shy diffidence about him that led him almost to shrink from public notice.... And yet he had a sort of pride about him, too. Solitude had made him self-reliant; I doubt if there ever was a man who was less dependent upon others. His philosophy of life rendered him absolutely detached, independent, and selfcontained....He was the architect of his own fortune... when success had fully crowned his arduous efforts, he settled down to use the wealth that came to him for the benefit of his fellow men. To be of service to others, on lines of his own choosing, was with him a passion. It inspired all his solitary thinking, all his careful planning and farsighted calculations. ${ }^{42}$

In a character sketch in 1923, architect Percy Nobbs found the same qualities of independence and generosity. He regretted that at the recent unveiling of
Macdonald's bust, ${ }^{43}$ not enough had been said of Macdonald's spiritual attributes and added

What is not so generally realized, as it might be, is that he was also a very kind, a very enthusiastic, a very punctilious, and a very modest old gentleman; in a word, that he had warm blood in his veins.

Nobbs declared that Macdonald was the students' best friend; that the motive for his philanthropy had not been fame or even the advancement of learning so much as his "simple and sympathetic affection, strongly felt, for all young men entering the battle of life with serious intent. " ${ }^{14}$ Nobbs may have been right. Macdonald did not give abstractly but out of personal interest in the cause or recipient. Lacking children, the students became his family. Anonymously, he paid the tuitions of many needy students. After his death, the Montreal Gazette noted how Macdonald had enjoyed walking around the campus he had befriended,

surveying the stately buildings which will remain for generations as a living monument to his memory, and enjoying the sight of the young men at play....For, although he lived very quietly, he had warm social instincts. He loved the young, which was the secret of his giving in many directions.... ${ }^{45}$

The McGill Daily added: "Especially was it his delight to walk into the Union unexpectedly, watch the students at billiards and enquire into the success of the operations of the building. "46 W.D. Howell pictured Macdonald standing at the lectern in his reading room piled high with books and reports, tirelessly pursuing many subjects, dreaming how "to turn gold into happiness, not for himself but for young people. ${ }^{\text {47 }}$

Macdonald left his own record of his concerns and friendships near the end of his life- his will. Probably taking warning from Stewart's stroke and his own declining health, Macdonald made his will on 25 August 1914. It specified that he be cremated in the Crematorium he had built on Mount Royal. He left legacies to his faithful employees: his coachman and three maids, and Superintendent Wells and two book keepers at his business. He left nothing to his relatives 
but singled out two McGill friends, Walter Vaughan ${ }^{48}$ and Principal William Peterson for legacies of $\$ 25,000$. Among the legacies he left to McGill was $\$ 20,000$ to establish a travelling scholarship to enable English speaking law students to study in France "as I deem it of great importance that the English speaking members of the legal profession should be proficient in the French language." He left $\$ 1,000,000$ to Macdonald College, $\$ 500,000$ to the Medical Faculty, $\$ 300,000$ to the Conservatorium of Music, $\$ 500,000$ to the Montreal General Hospital, $\$ 100,000$ to the Montreal Maternity Hospital, and $\$ 100,000$ to the Crematorium Company.

Most striking of all, he left his business and fortune estimated by the press at $\$ 20,000,000$ to Howard and Walter Stewart, the sons of David Stewart. ${ }^{49}$ In doing this, he recognized the crucial part the Stewarts had played in bis success. David Stewart died soon after Macdonald at the beginning of December 1917 at the age of seventy-three. Surprisingly little has been written about this man, who ran the company well, especially after Macdonald began to lose interest in it. Indeed, be freed Macdonald for philanthropy. Born in Edinburgh, Stewart came to Montreal around 1865 and worked with his brother James for the Penny-Wilson Company, owner of the Montreal Herald. Working for Macdonald since 1867, Stewart became closely identified with Macdonald, becoming his "confidential manager" and close advisor. In character and taste, he resembled Macdonald closely; he preferred a few close friends to fashionable society, collected books and loved to read Carlyle. ${ }^{50}$ His two sons worked for Macdonald as well. That Macdonald left his company to the men who had built up his business was generous and characteristic. His spiritual as well as financial heirs, the Stewarts continued Macdonald's support of McGill, particularly Macdonald College. They maintained the company successfully; in 1922 they mechanised the manufacture of cigarettes and won $15 \%$ of the Canadian market. The popular EXPORT marque appeared in 1928 and the trademark Macdonald lassie in 1935. In 1974 David Stewart, grandson of Macdonald's assistant, sold the company to R.J. Reynolds Tobacco Co. of Winston Salem, North Carolina and set up the MacdonaldStewart Foundation-perpetuating the philanthropy of William Macdonald and his Stewart heirs.

\section{THE MACDONALD LEGEND}

Anecdotes offer a consistent picture of Macdonald's character. They confirm his personal frugality, generosity to others, insistence on business accountability, dislike of religion, faith in education, dry humour, individualism, old fashioned tastes, loyalty to clan and country, pride, dislike of public notice, modesty, pleasure in friendship, and voracious reading. His photographs show that he had dark, handsome features when young, and a piercing glance and strong presence at all ages.

The first character sketch of Macdonald, lively though embroidered, was published by Augustus Bridle in 1916 as Macdonald lay ill and old. Calling Macdonald "a paragon of paradoxes", Bridle saw the dramatic possibilities of Macdonald's story: "There never was a Canadian Dickens to transcribe this man to a charactership in a novel, or he would have become one of the monuments of literature." Bridle made much of Macdonald's frugal life style, contrasting his "plain old terrace in Sherbrooke Street" with the "Modern castles at Westmount" built by the "other money barons". Van Horne and Strathcona had tried in vain to interest Macdonald in collecting paintings but Macdonald stuck to reality-his books. Exaggerating Macdonald's eccentricities, Bridle lauded bis greatness, suggesting that James McGill himself might agree that "the name of the big Anglo-Canadian University in bilingual Montreal should be changed to Macdonald University." ${ }^{51}$ (We doubt very much if James would have concurred!)

The image of Macdonald as a small, reserved, unassuming man has persisted, although his professors and others remembered Macdonald as bold and forthright. After all, he had threatened his fellow millionaires with ruin if they built the Ritz-Carleton with its bar next to McGill. ${ }^{52} \mathrm{He}$ sometimes took direct action on behalf of all Montrealers; when the City would not pay for vaccinations during the smallpox epidemic of 1885 , he stepped in with $\$ 25,000$ for the purpose. He also gave financial support to a civic investigation of charges against the police. ${ }^{53}$ Some anecdotes about Macdonald tend to be along the lines of the canny Scots businessman who wore his clothes until threadbare and saved string. Other stories stress his 
generosity-carefully planned to institutions but puckish and spontaneous to individuals. He enjoyed giving surprise gifts to women. A bride found the necklace she had coveted in a store on her plate at Macdonald's table; a young lady relative was told she might take the pictures in a cupboard drawer: the "pictures" were on hundred-dollar banknotes. ${ }^{54}$

Susan Vaughan, whose husband Walter received a bequest of $\$ 25,000$ in Macdonald's will, remembered his "fine democratic friendliness, which included in its circles not only statesmen and financiers but also women and children, to whom his gentle manners and sense of fun endeared him". She defined his charity as "mingled shrewdness and generosity":

He was not interested in supporting weakness and had no wish to assume responsibilities which belonged to others, but, once convinced that he had found a promising field, he poured out his irrigating wealth with a hand as lavish as it was unpretentious. ${ }^{\text {ss }}$

He took great interest in his professors-from Rutherford and Harrington to the horticulturalist Saxby Blair. Blair recalled Macdonald's unannounced visits to Macdonald College and the staff's curiosity to meet him. Macdonald refused to take up staff time but enjoyed watching the horticultural work and would ask questions if assured he was not interrupting. Blair sent him "the finest Montreal melon I ever saw from our planting at the College." Macdonald told him that all produce should be sold and added to the college funds. Once Macdonald sent the College carloads of tobacco stems to be plowed under; visiting, he noticed that some had been wasted. Blair and others observed that Macdonald hated waste and wanted materials that were considered useless saved for future use (an ecologist before his time). When Blair left the College, Macdonald wished him well but "was apparently annoyed at my decision.... he seemed to think I should have talked to him first." Blair felt that Macdonald " expected more than it was possible to accomplish quickly. I think he expected in this educational venture more instant and outstanding results such as were so evident in all the business undertakings he was associated with...." 56
Although shy, Macdoaald could be lively and witty in company with those who interested him. Unpretentious, mocking his modest height, he pointed out his Macdonald College buildings, saying "not bad for a little fellow". Agile, he climbed up on tables to inspect leaking ceilings and led the Principal of Macdonald College across a high beam in an unfinished building. He slept in an iron bed; he begrudged having a telephone because the public would have him by the ear; getting no answer at the door of Royal Victoria College, he climbed through the window; and he enjoyed watching the chicks hatch in the Macdonald College incubator. ${ }^{57}$

Proud of his Scottish ancestry, Macdonald had a memorable meeting with an even better known Scotsdescended philanthropist. When McGill gave Andrew Carnegie an honorary degree in 1906, Macdonald was sitting on the platform with Principal Peterson. According to J.C. Simpson, Carnegie had lunched too well and

rambled on about the inherent merits of the Scots. He spoke of the accomplishments of James McGill, William Macdonald and Andrew Carnegie, and wound up his remarks by saying "It takes a Scotchman to show them, eh Mac?"- -at the same time planting a resounding whack between the shoulders of Sir William Macdonald. ${ }^{58}$

Above all, religion divided Macdonald from his peers. Though disdaining denominations, he saw a divine direction behind the workings of nature and perhaps believed in a broad Supreme Being kind of religion. $^{59}$ Harrington found it curious that the irreligious Macdonald attended lectures by religious speakers such as Dwight Moody and Mrs. CarusWilson (wife of John Carus-Wilson, Macdonald's Prof. of Electrical Engineering). ${ }^{60}$ Obviously Macdonald liked to be provoked intellectually; he sought diversion. $\mathrm{He}$ enjoyed discussions and Latin tagging with two Jesuit relatives, Alain and Alastair Macdonald. ${ }^{61} \mathrm{He}$ objected less to Protestantism than Catholicism, probably because at sixteen he had reacted against his Catholic upbringing. His quarrel with his father, his preference for his Protestant mother, or something else may have uprooted his ancestral faith. Whatever the cause, his non-sectarianism was rare among his Montreal peers. 


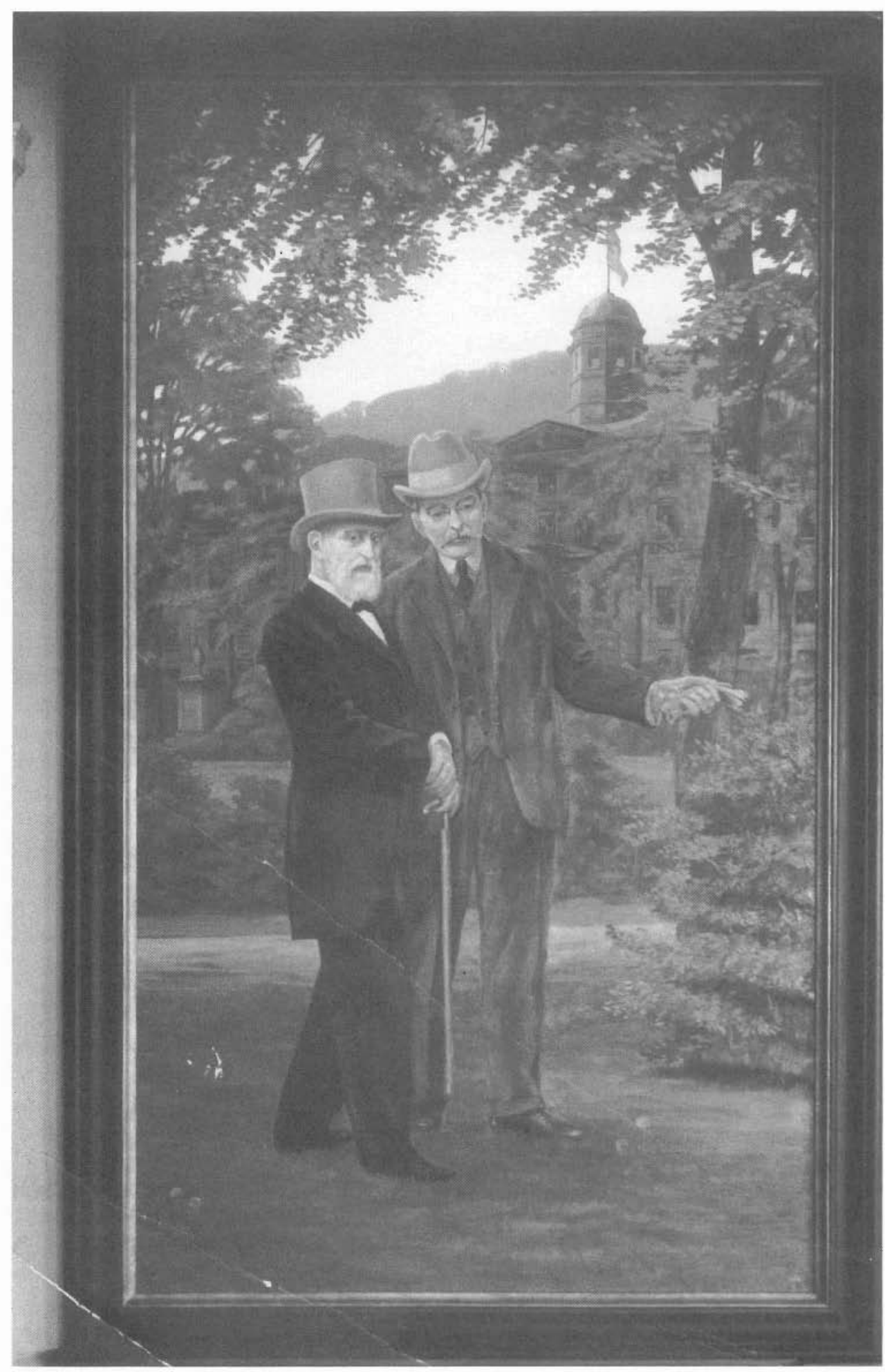

Macdonald and Peterson on the McGill campus, by Percy Nobbs; painting in Student Union Building which was designed by Nobbs and donated by Macdonald. (McGill University Archives) 
Macdonald has escaped analysis by the interdisciplinary approaches typical of modern biography. An economic or marxist historian might blame him for selling what we now know to have been an unhealthy product, made by low-paid workers, or charge that his generosity to education entrenched a middle class of managers, teachers and farmers. A French-Canadian historian might notice that his workers were French, his objects of charity mainly English. A feminist would point out that over half bis workers were fernales, paid less and managed by males, that his educational beneficiaries were mostly males, and that he tried to dominate his niece. A psychological historian might dwell on his rejection of father, religion and marriage. Such one-issue approaches would be ridiculously incomplete; Macdonald must be seen in a broad context and recognized for the wild card that he was.

He was an original, lonely, very successful man who grew with his wealth. He may have started out trying to regain his lost social status or making money for its own sake but by middle age he found himself bored with business, without children, and disdaining wealthy display. A reader when alone, he found he enjoyed building educational institutions and helping students. Like other capitalists, he ran his company on "business principles"; unlike them he gave much of his profit to the self-helping cause of education and at last gave the business away to his manager's sons. His accomplishments are well known; our knowledge of the inner Macdonald remains provocatively incomplete-an invitation to further exploration.

\section{PORTRAITS}

Portraits of Macdonald by Robert Harris, Wyatt Eaton, R.S. Newton, and a bronze bust by H.P. MacCarthy, as well as the Nobbs painting with Peterson, are at McGill or Macdonald College. There are photographs at various ages by Notman.

\section{Acknowledgements}

For insights into Macdonald's personality and other information, we are indebted to Victoria Stewart. We have also been helped by Clayton Gray, Professor Peter
McNally, Carol Wiens, and Emile Edgett, Superviseur, Relations Publiques, RJR-Macdonald Inc.

$\begin{array}{ll}\text { Abbreviations } & \\ \text { MUA } & \text { McGill University Archives } \\ \text { RG } & \text { Record Group } \\ \text { RG 4 } & \text { McGill Board of Governors Records } \\ & \\ \text { MG } & \text { Manuscript Group } \\ \text { MG 1022 } & \text { Dawson Family Papers } \\ \text { MG 2007 } & \text { J.F. Snell Papers } \\ \text { C } & \text { Container }\end{array}$

\section{Notes}

1. He changed his signature from "McDonald" to "Macdonald" after his knighthood in 1898. The latter spelling is used here; both spellings occur in documents after 1898 .

2. John Ferguson Snell, Macdonald College of McGill University (Montreal 1963). Pages 1-34, 201-207 of this work together with Snell's "Sir William Macdonald and his kin", Dalhousie Review (Oct. 1943) provide important information on Macdonald's background, youth, and relations with his family as well as many brief anecdotes illustrating his character and humour. Snell's papers include information about Sir William collected ca, 1937 by S.R.N. Hodgins, Assist. Prof. of English, Macdonald College. Memories of Macdonald are also found in various articles in the McGill News, press obituaries (June 1917), and E. A. Collard, "Sir William Christopher Macdonald", Montreal Gazette, 4 \& 6 Mar. 1946.

3. Snell, "Sir William Macdonald" is the source for most information on Macdonald's youth.

4. Snell, "Sir William Macdonald", 10-11.

5. Mackay's Montreal Directory, for 1866-67, 281.

6. Snell, Macdonald College, 226.

7. Ibid., 13-14.

8. Snell, Macdonald College, 225-226; New York Sun, Herald, Telegraph, World, 29 Oct. 1885; R/R-Macdonald Inc, 1858-1993 (publicity folder); Macdonald Tobacco Inc. (publicity pamphlet, ca. 1977); Bettina Bradbury, Working families (1993), 27-28; Lyal Tait, Tobacco in Canada (1968), 60-73; and see entries under "Tobacco" in the editions of The Canadian Encyclopedia.

9. The Commission consisted mostly of Tories in business, representatives of labour, and journalists; they split and presented two reports in 1889 . They agreed, however in condemning child labour and called for legislation by all 


\section{Sir William Macdonald: An Unfinished Portrait}

provinces to prohibit the employment of children under fourteen. Although the Commission's recommendations were largely ignored, increasing mechanization and need for skilled workers eventually cut the demand for child labour. See Desmond Morton with Terry Copp, Working People (Ottawa 1980), 43 44; Lorna F. Hurl, "Restricting Child Factory Labour in late Nineteenth Century Ontario", Labour/Le Travail 21 (Spring 1988), 96.

10. Report of the Royal Commission on the relations of capital and Labor in Camada (Ottawa 1889), 529.

11. F.C. Harrison, "Reminiscences of the Founder of Macdonald College", Otd McGill, 1927, 102, 341.

12. Montreal Daily Star, Montreal Gazette, La Patrie, La Presse, 26 April-10 May, 1895.

13. This sum may have been set to prevent an appeal to the Supreme Court.

14. Canada: Province of Quebec, District of Montreal. In the Court of Queen's Bench (Appeal Side). William C. McDonald, (Defendant in the Superior Court), Appellant; and Désiré Thibaudeau, et uxor, (Plaintiffs in the Superior Court), Respondents.

-Appellant's Factum. 72pp. 1899.

-Appellant's Appendix. Judgement in the Superior Court [in 1897]. No. 1557. 173pp.

These two documents were printed in limited quantities as was customary in such cases. Citations here are to the Appellant's Factum (1899).

15. Samuel Pagnuelo had led attacks ca. $1887-1890$ on the quality of McGill's law training, advocated the supremacy of the Bar over admission to the legal profession, and had a controversy with McGill's Principal which had FrenchCatholic vs. English-Protestant overtones. Without prejudice, it may be pointed out that Justice Pagnuelo may have known in 1897 that Macdonald had become McGill's chief benefactor and had given the Faculty of Law $\$ 150,000$ in 1895. The Thibaudeau case, pitting French Canadian working class plaintiffs against a Scottish-Canadian millionaire had a certain archetypal drama.

16. Born in Montreal in 1838, Hutchison supervised stone cutting for Christ Church Cathedral (Montreal) and the East Block, Parliament (Ottawa). He practised until 1890 with $O$. Steele, then with George Wood. He designed several Montreal churches including the Erskine and American on Sherbrooke St., business bulddings and residences including that of Lord Strathcona. He submitted a plan crossing the MeGill campus with a row of buildings in the style of his Redpath Museum, blotting out the Arts Building to the rear. See John Bland, "In advance of all others", McGill News (Summer 1962), 9. The drawing, "Design for new buildings, McGill University" is held by the National Gallery of Canada (no. 235, $63 \times 150 \mathrm{~cm}$ ). The University would not have had the resources to construct Hutchison's scheme and it is unclear whether he got any encouragement or whether it was an enjoyable pipe dream; Principal Dawson may have been thinking of Hutchison's plan when he drew two proposed buildings on to a copy of the published plan of the campus (1888): see the MUA information file on Hutchison, letter by John King, 19 Jan. 1981.

17. Appellant's Factum, 53.

18. Appellant's Appendix, 4.

19. McGill Daily, 1 Oct. 1917.

20. Ibid.

21. Montreal Herald, 11 June 1917.

22. McGill Daily, 1 Oot 1917.

23. MUA, RG 4, C 3, file 9003 , Board of Governors' minute book, 14 Nov. 1870, 496-7; RG 4, C 289, files 9035-9037, Estate Committee's minute books, 1869-1894. Macdonald was enlisted for the Estate Committee by 29 June 1885 and appears to have left it by mid 1891.

24. Prof. Peter McNally points out that Peter Redpath's father John earlier had supported the Mechanics' Institute-which had a library and museum-the very areas Redpath oreated for McGill.

25. MUA, MG 1022, C 41, J.W. Dawson correspondence [Administrative] 1870, WCM to JWD, 30 March 1870.

26. MUA, RG 4, C 504, file 6794: "Sir William Macdonald", letter, Macdonald to Dawson, 9 April 1885.

27. MUA, MG 1022, C 62, letter, B.J. Harrington to Anna D. Harrington, 2 July 1896.

28. MUA, MG 1022, C 62, letter, B.J. Harrington to Anna D. Harrington, 17 July 1898; Snell, Macdonald College, 3031.

29. MUA, MG 1022, C 17, J.W. Dawson letters, July-Sept. 1895, Dawson to Macdonald, 31 Aug. 1895 (presumably a draft or copy).

30. MUA, MG 1022, C 17, file "January 1896", letter, W.C. Macdonald to J.W. Dawson, 16 Jan. 1896.

31. MUA, RG 4, C 504, file 6793: "Sir William Macdonald Donations for McGill", letter W.C. Macdonald to W. Vaughan, 22 Nov. 1899.

32. MUA, MG 1022, C 68, letter, Anna D. Harrington to R. Dawson, 28 Nov. 1899.

33. Maurry Epstein, "Sir William Macdonald: benefactor to education", M.A. Thesis, McGill University (1969), 107.

34. Like his fellow merchants, Macdonald sat on a few boards-the leading stockholder in Bank of Montreal, he was a governor of Montreal General Hospital and of Royal Trust Co.; a director of the Montreal Citizen's Association and of the Montreal Parks and Playgrounds Association; governor of the Lady Stanley Institute, Ottawa; member of the Protestant Committee of the Quebec Provincial Council of Public Instruction; and a vice president of the St. John Ambulance Association. He spent little time in his clubs: the Mount Royal Club and the St. James Club.

35. Snell, Macdonald College, chapter 4.

36. MUA, MG 1022, C 62, letter, B.J. Harrington to Anna D. Harrington, 9 Dec. 1894 . If more were known, the affair might take shape as a great Canadian romance, flavouring the 


\section{Sir William Macdonald: An Unfinished Portrait}

antagonisms of French and English, and Catholic and Protestant, against the background of universal conflicts between youth and age and men and women. Harrington added that he feared Macdonald was avoiding him, fearing his lobbying for a Chemistry Building: "Whether he is afraid that I will talk laboratory to him or not I do not know. Certainly he seems to have given up all idea of doing anything in that line for the present."

37. Snell, Macdonald College, 12.

38. MUA, MG 2007, letter, Anna M. Walsh to J.F. Snell, marked by him as 2 May 1943.

39. MUA, MG 2007, letter, Anna M. Walsh to J.F. Snell, 16 Sept. 1943.

40. Snell, Macdonald College, 31-2.

41. MUA, MG 1022, C 62, letter, B.J.Harrington to Anna D. Harrington, 13 Sept 1895.

42. Peterson's speech was transcribed in the Montreal Star and Montreal Gazette, 13 June 1917, and Snell, Macdonald College, 15-17.

43. In 1940 Nobbs told Snell: "Thank God I had nothing to do with the dreadful bust... The only good portrait of him is in the McGill Union (by me). It was based on two very lucky snapshots which I think I have." MUA, MG 2007, Snell Papers, file: "Sir William Macdonald: Ontario and Quebec letters", letter, P. Nobbs to J.F. Snell, 7 July 1940. Nobbs probably painted the dual portrait in about 1921, perhaps hoping to be paid for it, but donated it to the Students' Union in 1925: McGill University Libraries, Canadian Architecture Collection, Percy Nobbs Papers, Architectural Operations, Box 2, file on the painting.

44. Percy Nobbs, "Sir William Macdonald: some reminiscences by P.E. Nobbs", McGill News (June 1923), IV, no. 3, 1-2,4.

45. Montreal Gazette, 11 June 1917.

46. McGill Daily, 1 Oct. 1917.

47. W.D. Howell, "William Christopher Macdonald", McGill News, 13, no. 3 (June 1932), 32.

48. Vaughan had been William Van Horne's secretary; Macdonald had persuaded Van Home to release Vaughan to serve McGill as Bursar. Macdonald frequently dealt with Vaughan as the University's financial manager.

49. MUA, RG 4, Board of Governors, C 504, file 6797: "Sir William Macdonald, donations" (copy of Macdonald's will). 50. Montreal Star, 3 Dec. 1917.

51. Augustus Bridle, Sons of Canada (Toronto 1916), 3-10. Bridle, presumably a tobacco smoker or chewer gave a lyrical description of Macdonald's source of wealth: "... tobacco was a Canadian institution. Lumber camps were as much in need of tobacco as a modern army.... [the tobacco was used in] Lumber camps, mining camps, capital Eskimo igloos, prospector's tents, and Indian teepees; in half-breed shacks and factory yards; on trains and steamships and trails; in the outer-most marches of the Arctic here the hip-pocket and its plug are a constant joy; on the soft-blowing Pacific where the weed from Montreal is as common as canned salmon; on the cod-banks of the Atlantic where the fisherman's pipe is the joy of living; and even in down-town clubs of Canadian cities you will find men who, scorning the fine-cut and the patent package, discreetly haul out from the hip pocket a plug of Macdonald tobacco and proceed to demonstrate the joy that comes from the art of getting ready to smoke.... There was great stimulus to the imagination in one of those plugs of tobacco. Molasses laden, gummy and black, it told the story of the tobacco plant growing like weeds, packed and baled and ported to the wharves of Montreal, whopped with fragrant emphasis into the warehouses of Macdonald, ripped and torn loose, sorted and stripped, flavoured and pressed, stamped and ready for the case, the counter, and the camp." Bridle claimed that Macdonald had taken a personal interest in the manufacture of his plugs; that he had impressed plantation owners in the American South as a hard buyer; that he had closely supervised his factory; that he had taken paternal care of his factory hands; that he kept up with manufacturing trends and faced labour commissions by himself rather than through his managers.

52. Snell, Macdonald College, 204.

53. Montreal Star,11 June 1917.

54. Ibid., 30.

55. Ibid., 30.

56. MUA, MG 2007, Snell Papers, file: "Anecdotes of Sir William Macdonald", letter, W. Saxby Blair to S.R.N. Hodgins, 19 March 1937

57. Snell, Macdonald College, 18-34.

58. MUA, MG 2007, Snell Papers, file: "Anecdotes of Sir William Macdonald", letter, J. C. Simpson to S.R.N. Hodgins, 16 May 1937.

59. Snell, Macdonald College, 33-34.

60. MUA, MG 1022, C 62, letter, B.J. Harrington to Anna D. Harrington, 9 Dec. 1894.

61. Montreal Gazette, 11 June 1917. On Macdonald and religion, see Snell, Macdonald College, 194-195. 


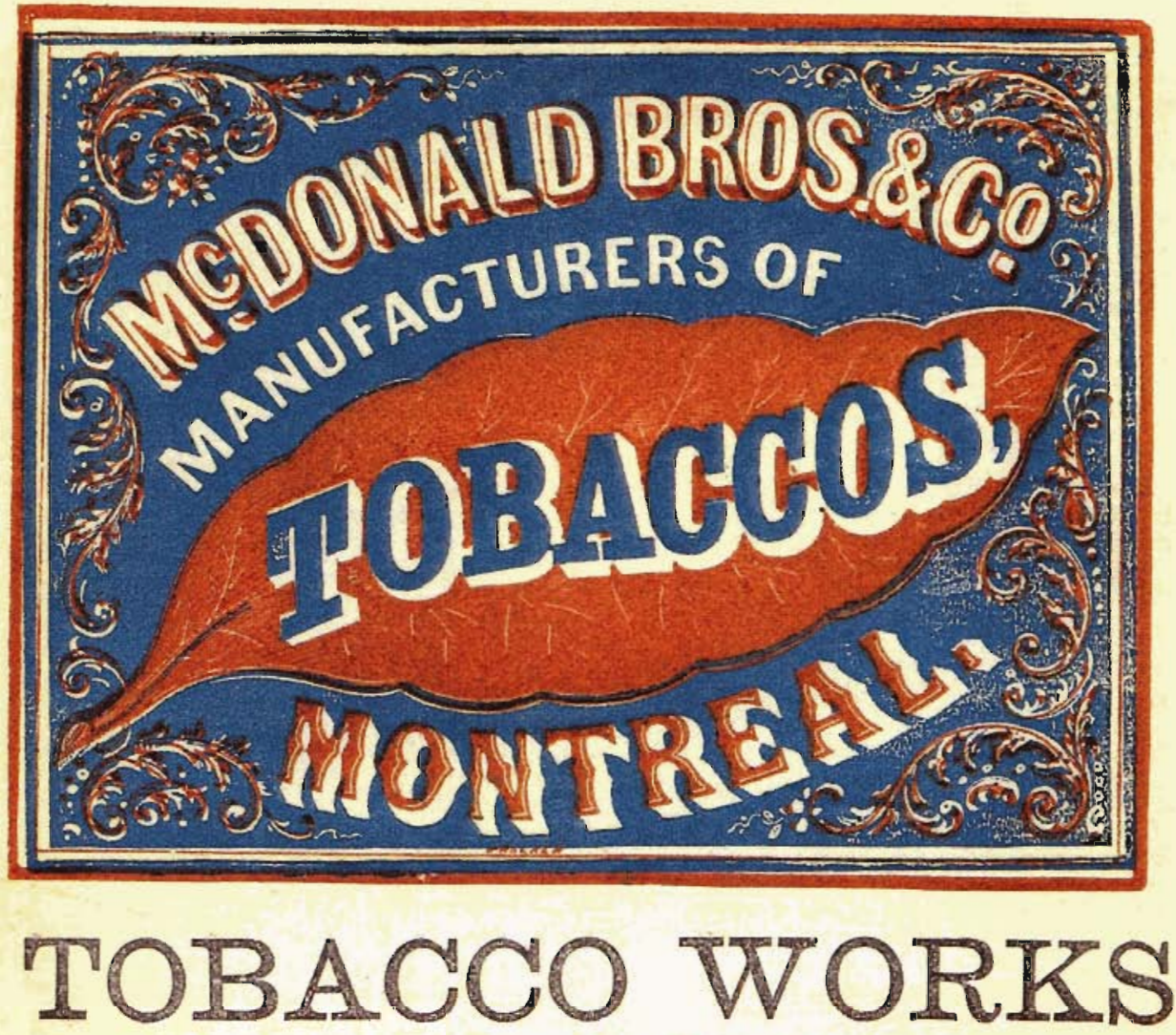

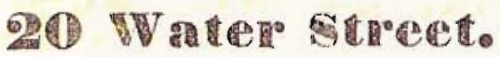

Messrs, FORESTER, MOIR \& CO.,

17 St. HELEN STREET,

Ade $A$ gents for the shle in Gannda, of alli our Tobnecos.

We manufacture the following WELL KNOWIN and FAVOURITE BRANDS:

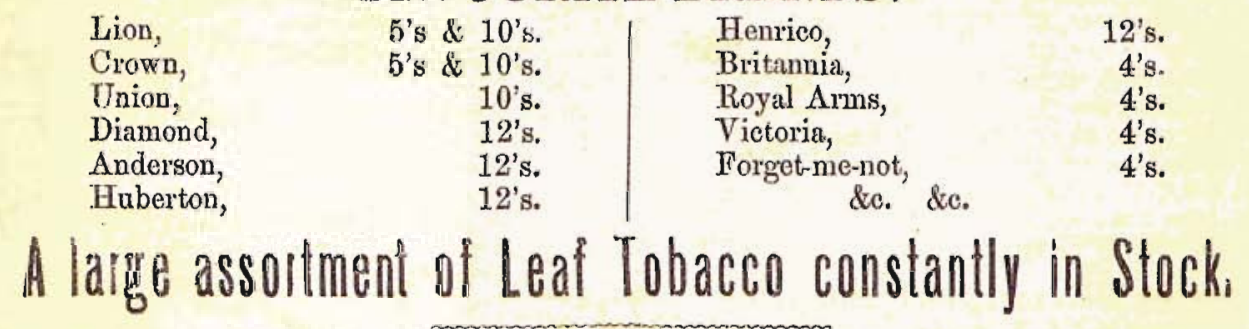

Shippers and other large buyers can purchase from us with unusual alvantage, our Tobaccos being made to keep in any climate.

CAUTTION.

As soreral manufacturers have imitated our "Cnows" nnd "Dssmoso" brands, our card an Irade Mark, as above, will be heroufter stencilled upon every $130 x$, for protection. to the Trade as buyors, and to oursolves as manuficturers.

Macdonald Bros. Tobacco advertisement in Mackay's 1864-65 Montreal Directory. (McGill University Libraries, Department of Rare Books and Special Collections) 


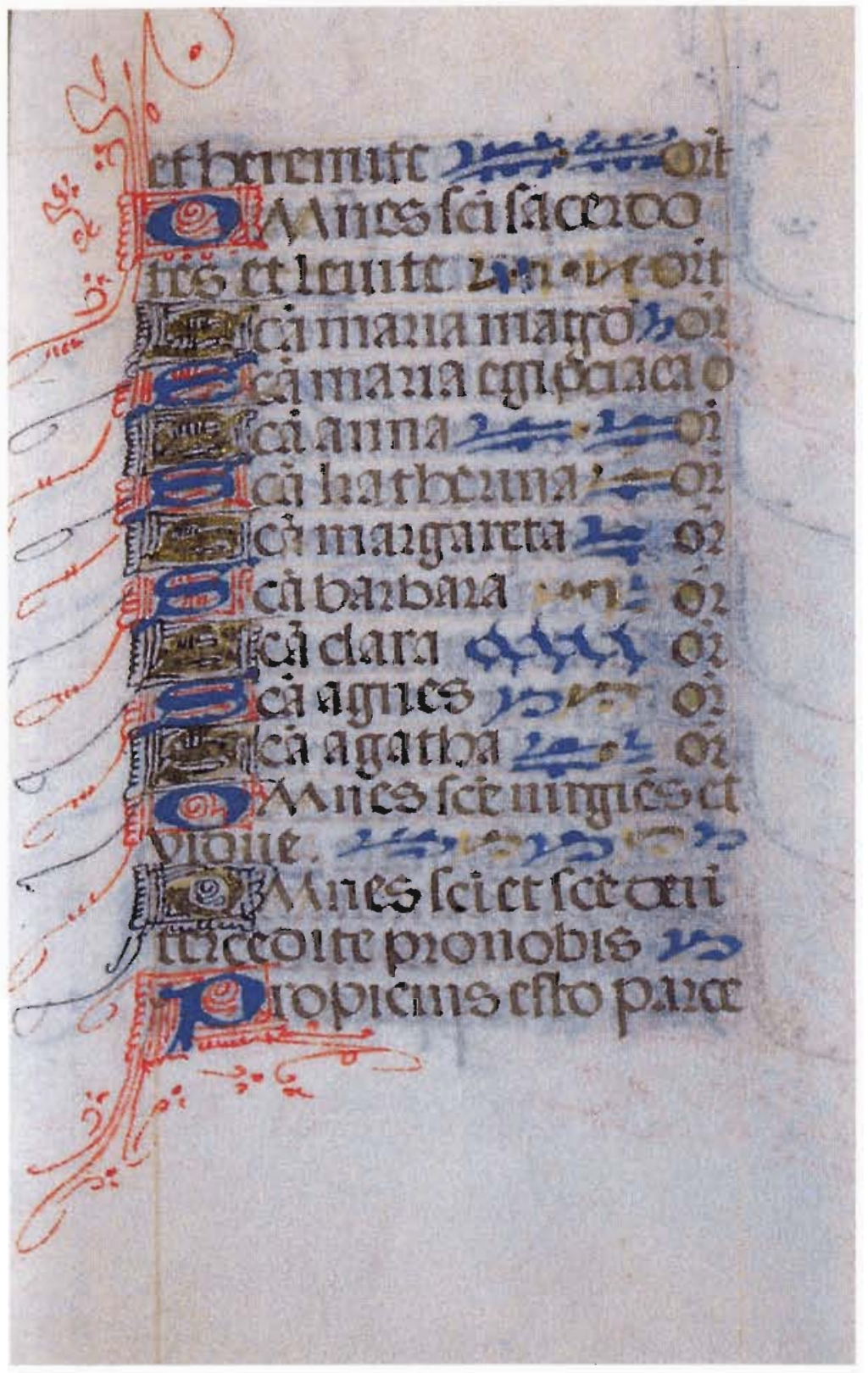

Figure 1. Litany to the Saints, gold and black, red and blue ink on vellum.

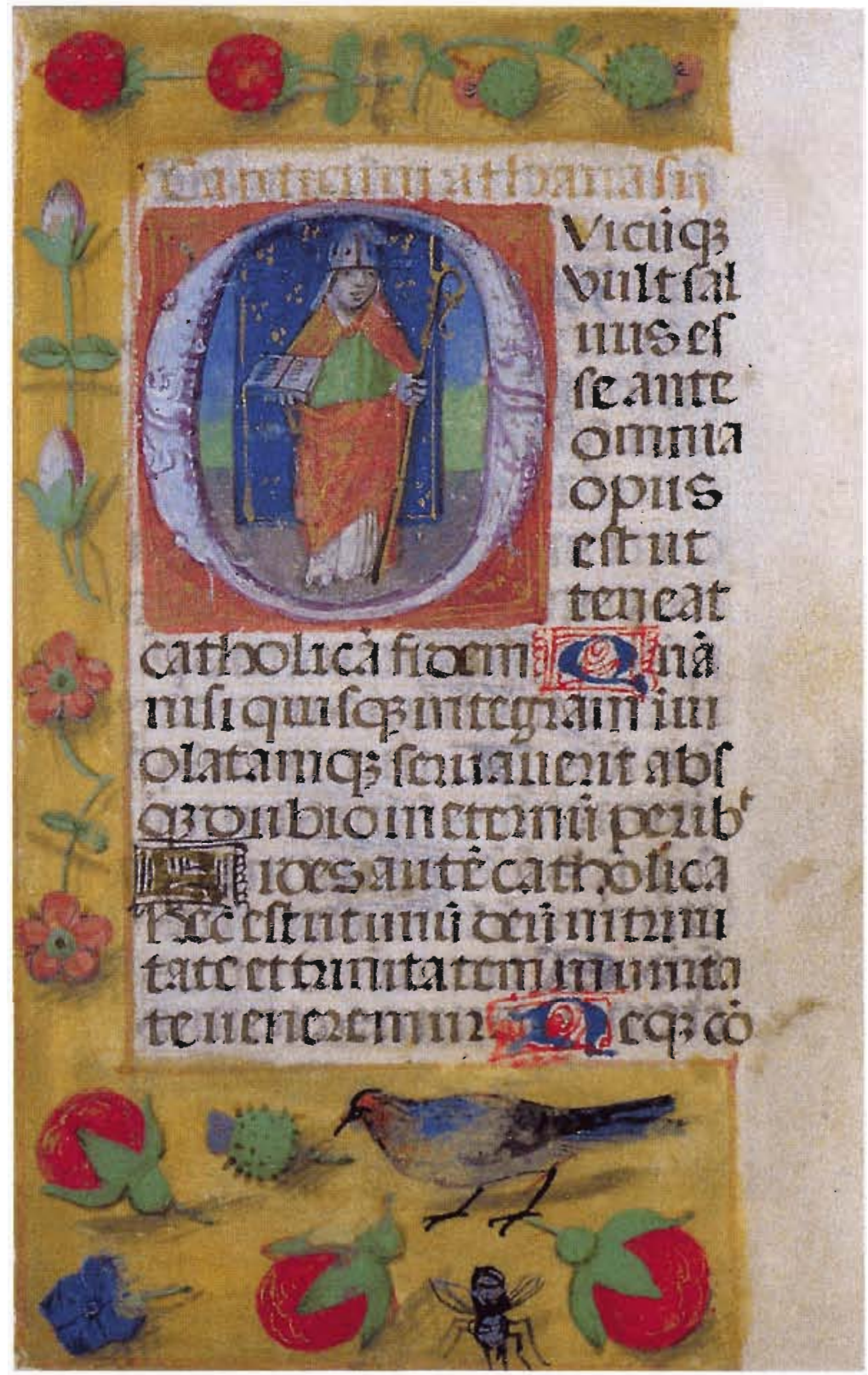

Figure 2. 'Historical Capital' with St. Athanasius, tempera and gold on vellum. 

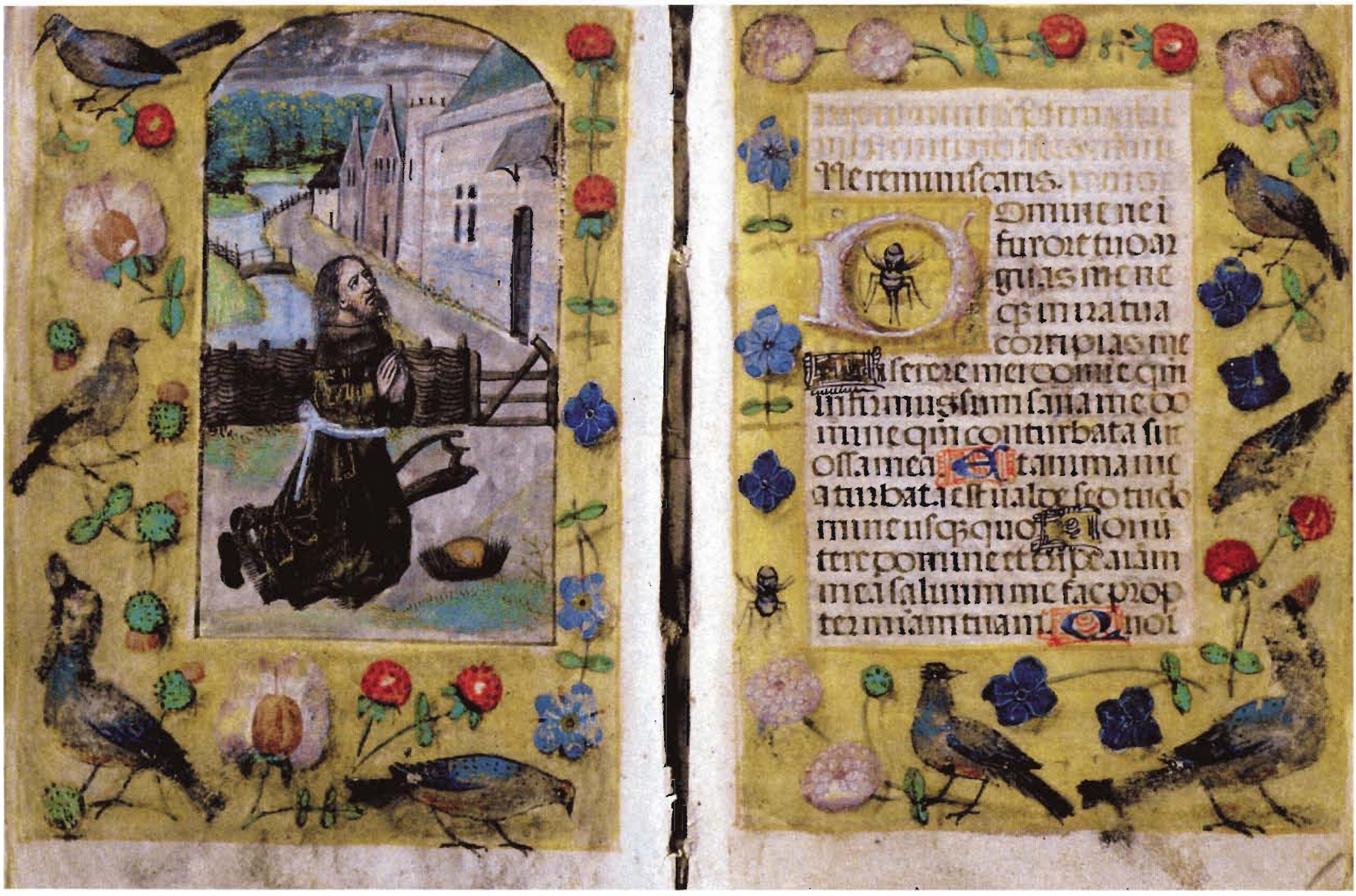

Figure 3. David in Penitence, tempera and gold on vellum. 


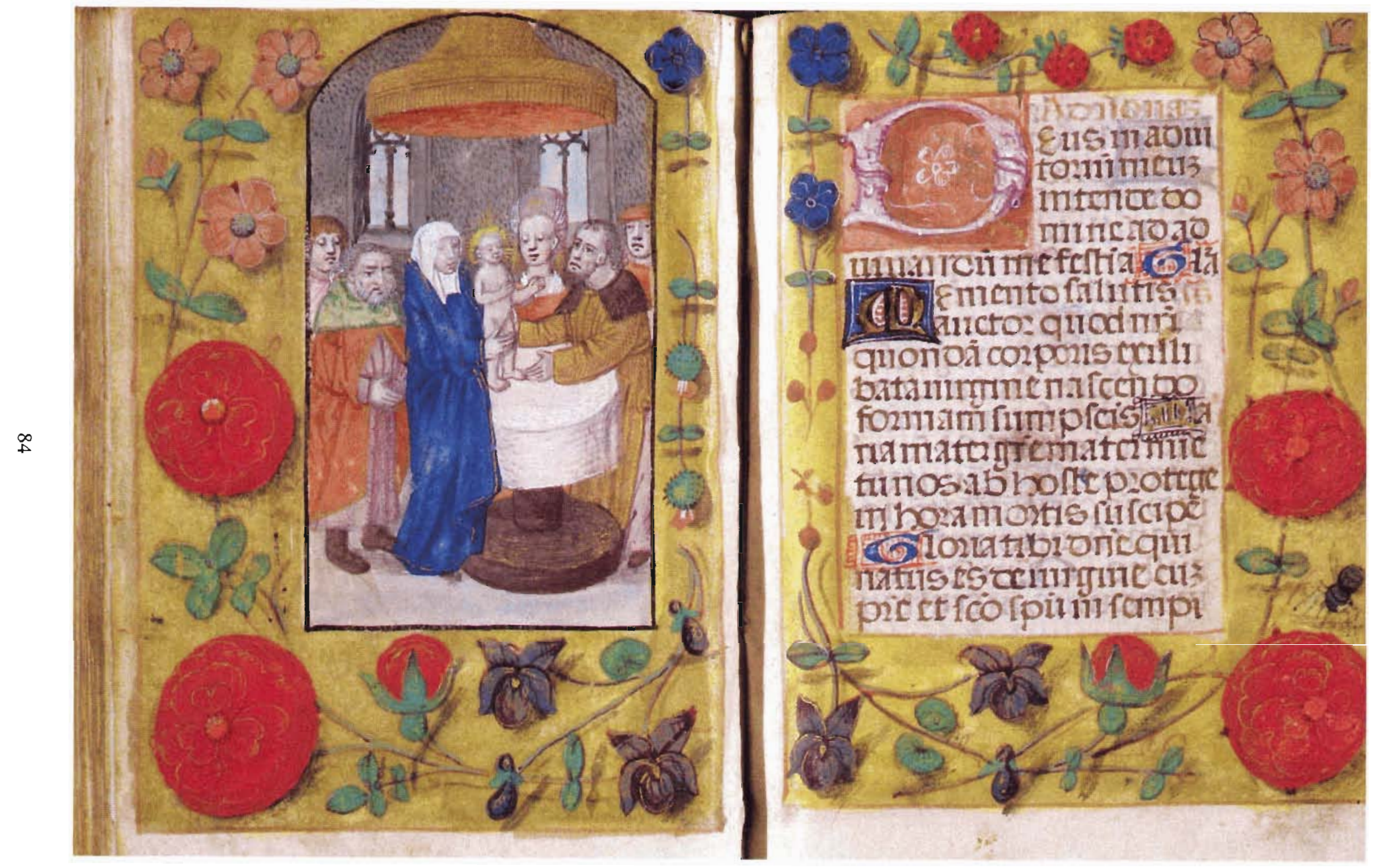

Figure 4. Presentation in the Temple, tempera and gold on vellum. 
meorfangumbonis a us falitis merct exilta bitlnugug mequificia3

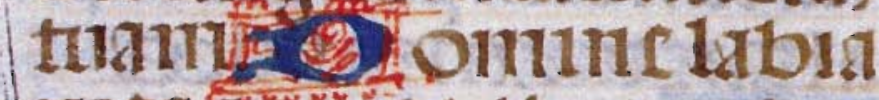

4. men

* annunciabit lanó tnaz

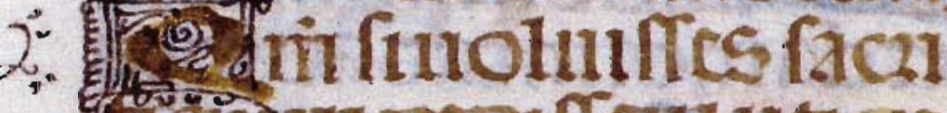
ficintur oxoinemintia

holocanilis norr oelecta bens fóscontibulatis $\mathrm{CO}$ contutumct himnlia tum oris non offora Es in bona bolintate tuafy oniteoificentur muti Itring

Figure 5. 'Calligraphic Embellishments,' tempera and gold on vellum. 

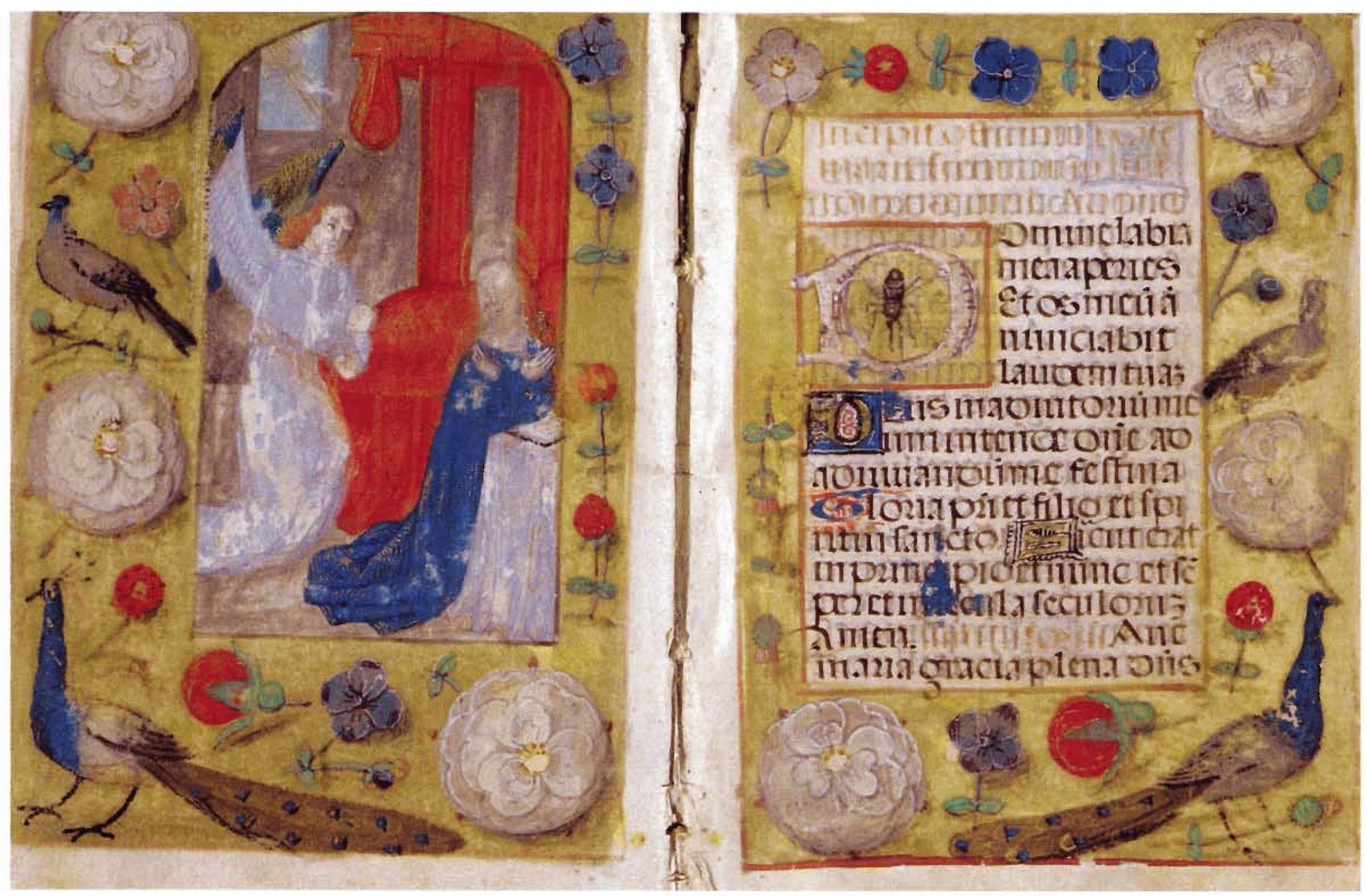

Figure 6. The Annunciation, tempera and gold on vellum. 

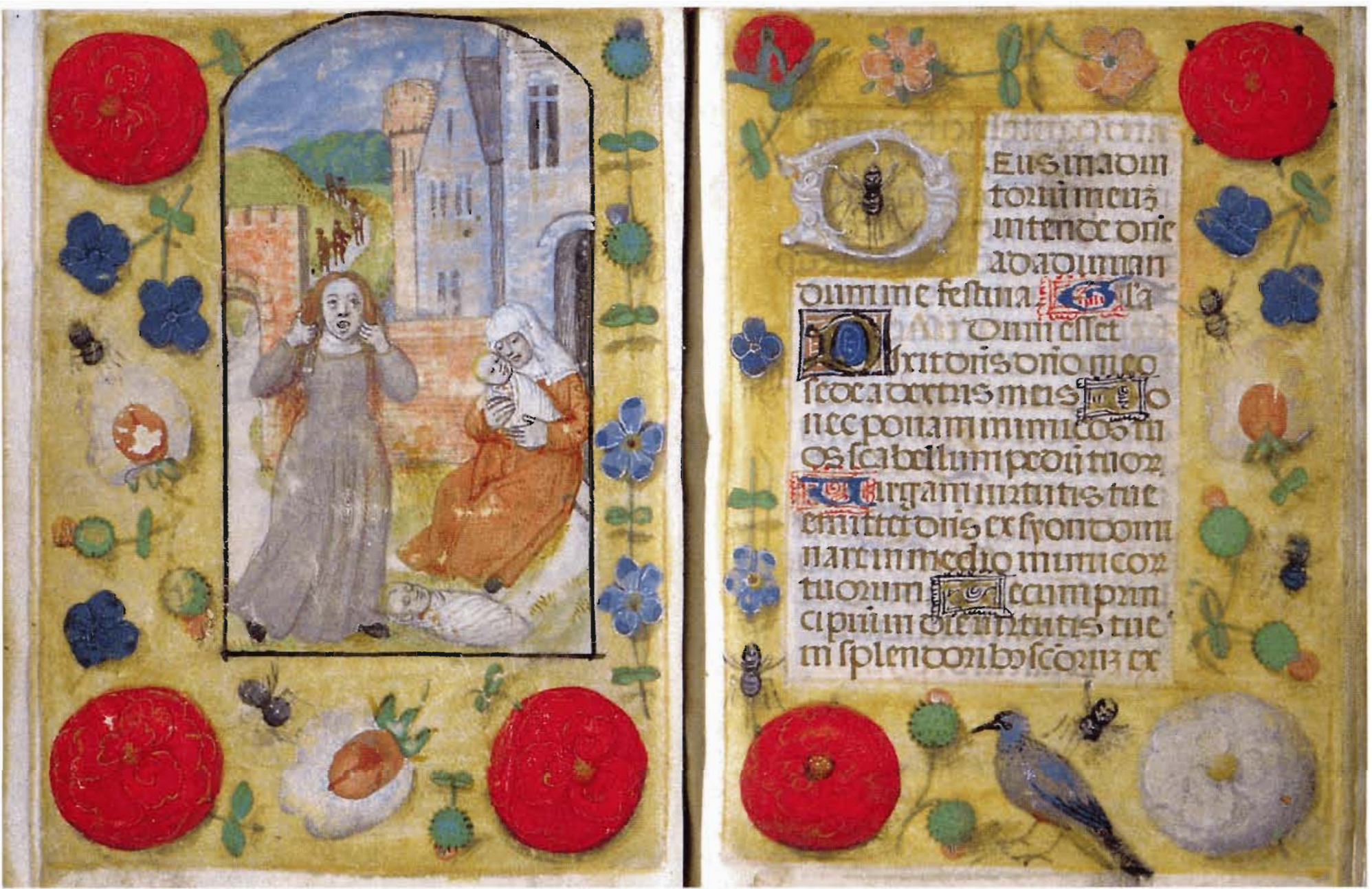

Figure 7. Massacre of the Innocents, tempera and gold on vellum. 

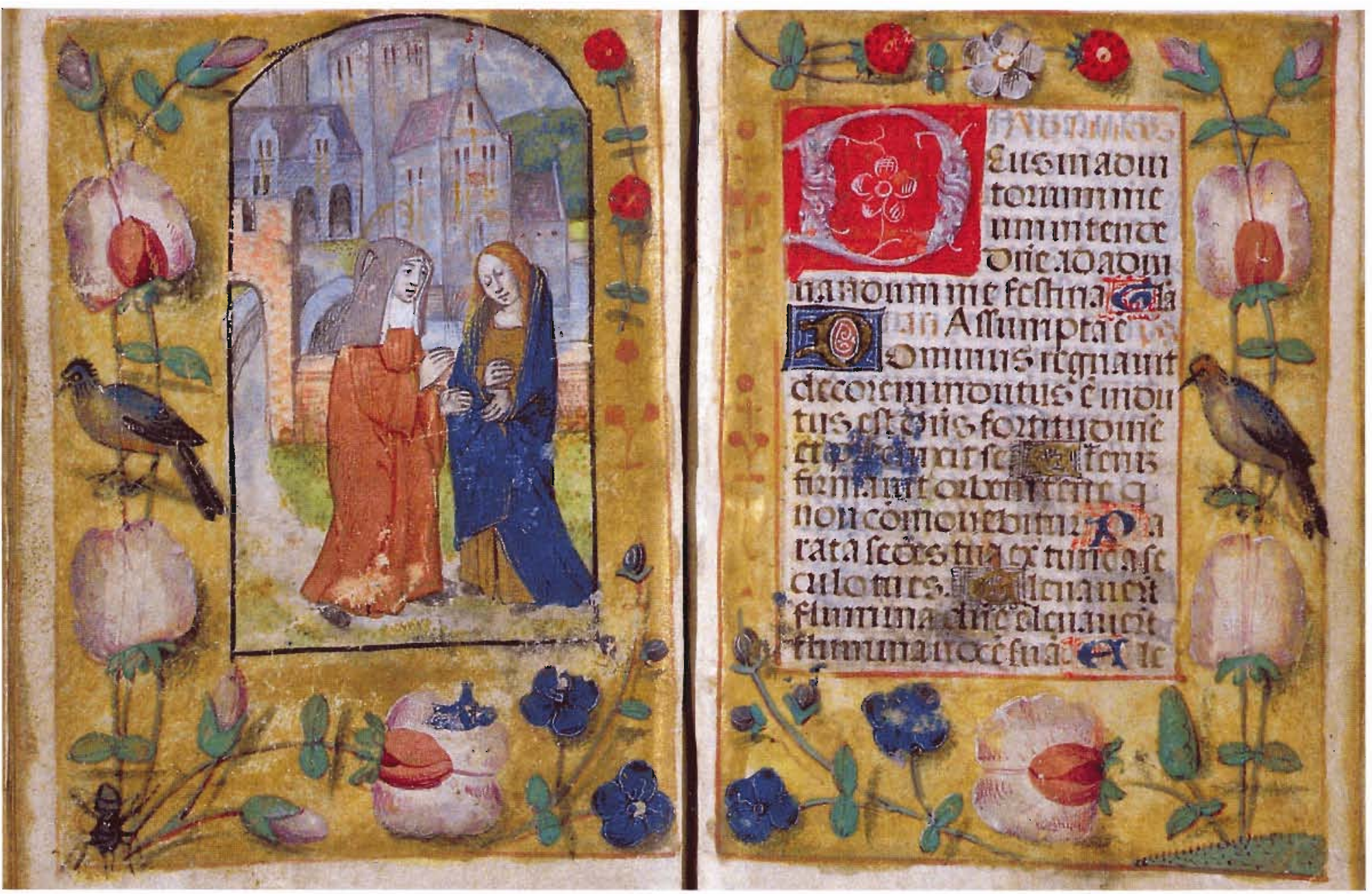

Figure 8. The Visitation, tempera and gold on vellum. 

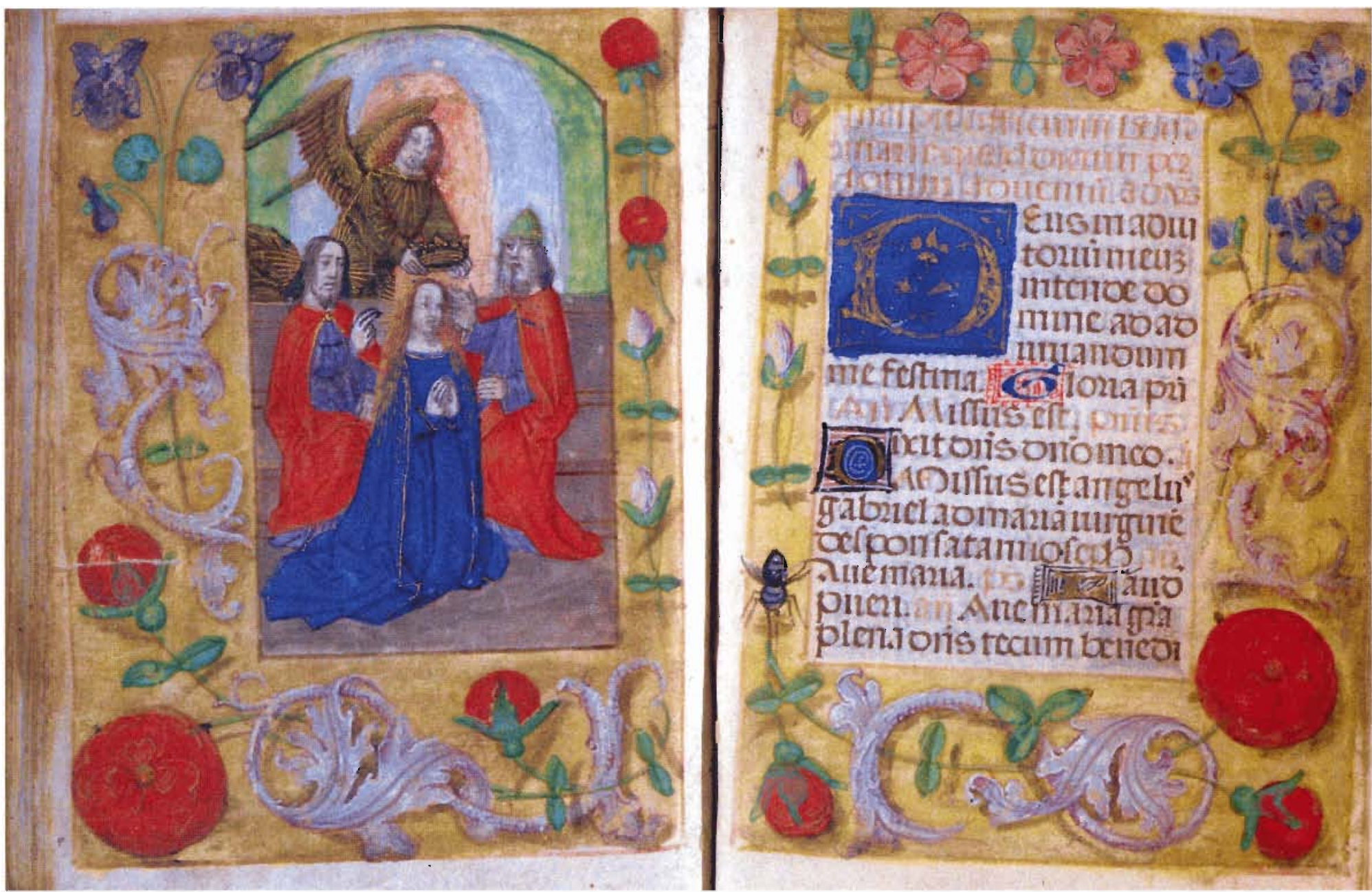

Figure 9. Coronation of the Virgin, tempera and gold on vellum 


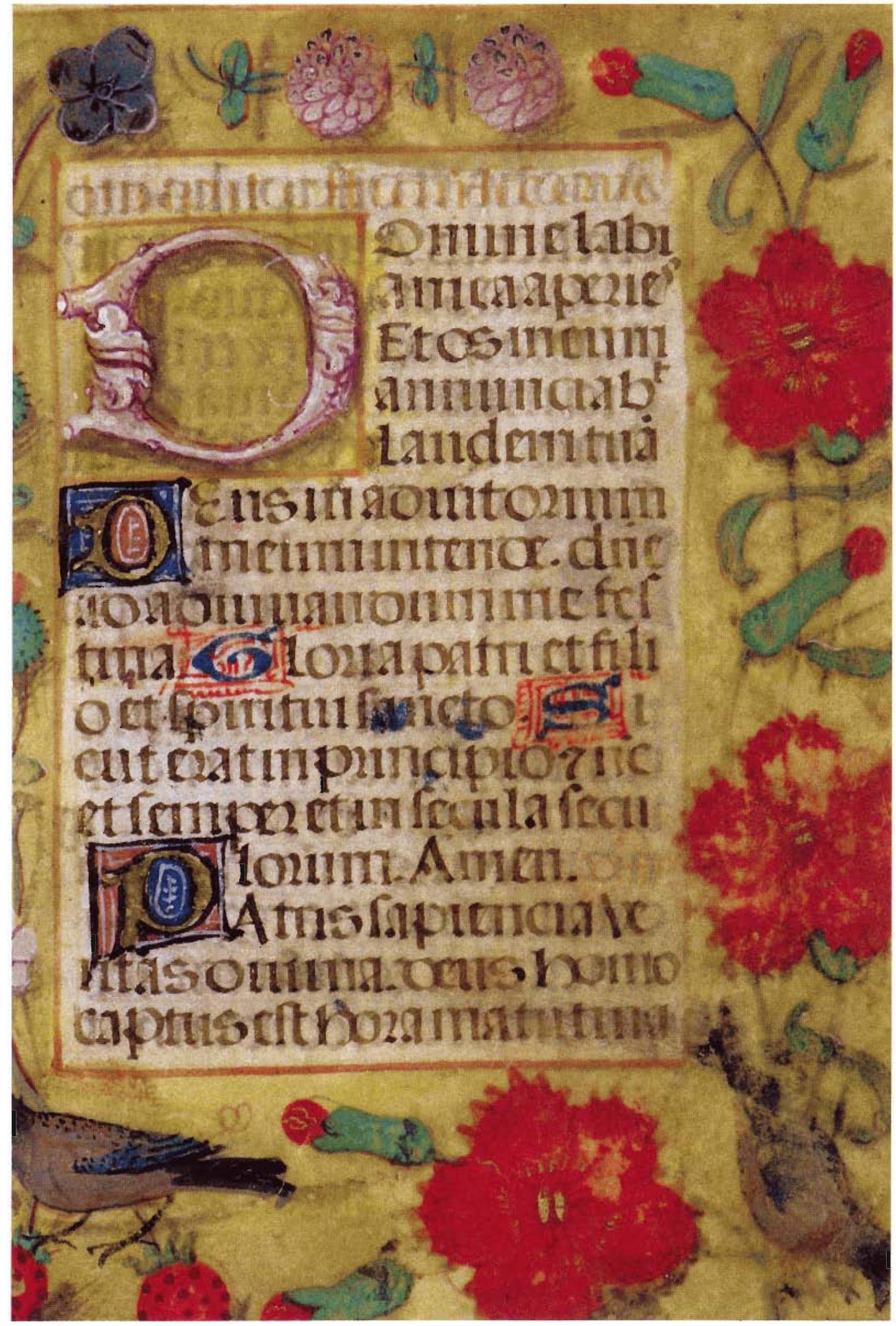

Figure 10. Folio $13^{x}$, tempera and gold on vellum. 